\title{
st \\ A ciência visual de Leonardo da Vinci: notas para uma interpretação de seus estudos anatômicos
}

\author{
Eduardo Henrique Peiruque Kickhöfel
}

\section{INTRODUÇÃO}

Leonardo da Vinci realizou investigações anatômicas entre 14.85 e 1515, datas aproximadas que marcam seus primeiros estudos sobre ossos, músculos e nervos, realizados em Milão, e seus últimos estudos sobre o feto humano, realizados em Roma. ${ }^{1}$ No dia 10 de outubro de 1517, em visita a Cloux, onde Leonardo vivia a convite de Francisco I, Antonio de Beatis, secretário do cardeal Luis de Aragon, escreveu que Leonardo compusera volumes "a respeito de membros como músculos, nervos, veias, articulações, intestinos e de quanto se pode pensar tanto de corpos de homens como de mulheres, de modo que ainda não foi feito por outra pessoa, conforme vimos com nossos olhos". Leonardo disse então a Beatis que havia feito a anatomia de "mais de trinta corpos entre homens e mulheres de todas as idades", e Beatis ainda menciona que havia uma "infinidade de volumes" escritos "todos em língua vulgar, os quais se vierem à luz serão úteis e muito prazerosos" (apud Chastel, 1987, p. 243). Os manuscritos não foram publicados como Beatis esperava. Após a morte de Leonardo, ocorrida em 1519, seu aluno Francesco Melzi levou-os de volta para a Itália e compilou o Livro de pintura, que circulou sob a forma de cópias manuscritas. Após a morte de Melzi, ocorrida em 1570, seu filho Orazio começou a dispersar os manuscritos de Leonardo da Vinci. Por volta de 1590, o escultor Pompeo Leoni adquiriu diversos manuscritos e fólios soltos. Da coleção pertencente a Leoni, ainda existem diversos manuscritos inteiros, talvez como estavam na época de Leonardo. Leoni também desmontou manuscritos, organizando dois grandes volumes. O primeiro intitula-se Disegni di machine et delle altre secreti

1 A primeira data presente nos estudos em questão está no fólio K/P 40 recto: “a 2 de abril de 1489". Esse fólio é contemporâneo aos fólios aqui numerados 6 e 7. Por questões de matérias e estilo, considera-se anteriores a 14.89 uma pequena série de fólios, entre os quais os fólios aqui numerados de 1 a 3 . A última data está no fólio K/P 168 verso: "no dia 9 de janeiro, 1513 ”. Esse fólio é contemporâneo aos fólios aqui numerados de 3 o a 33. 
et altre cose di Leonardo da Vinci raccolti da Pompeo Leoni. Esse é o conhecido Codice Atlantico, pertencente à Biblioteca Ambrosiana de Milão, e contém principalmente estudos de máquinas, como seu título sugere. O segundo tem por título Disegni di Leonardo da Vinci restaurati da Pompeo Leoni. Esse volume chegou à Inglaterra no século xvII, possivelmente através de Thomas Howard, conde de Arundel, que desde então pertence à família real inglesa, estando depositado na biblioteca do Castelo de Windsor. Esse volume contém a principal coleção de desenhos de Leonardo da Vinci, incluindo praticamente todos os estudos de anatomia.

Excetuando o Livro de pintura, publicado em Paris em 1751 e conhecido desde então como Tratado da pintura, os textos de Leonardo da Vinci ficaram praticamente desconhecidos até o final do século xIx. As primeiras edições foram feitas por RavaissonMollien, Beltrami e Piumati por volta de 1880, e desde então a obra de Leonardo está disponível em diversas edições. Especificamente a respeito da anatomia, as primeiras duas edições foram publicadas por Sabachnikoff e Piumati (Leonardo da Vinci, 1898, 1901). A terceira edição foi publicada em seis volumes por Vangensten, Fonahan e Hopstock, e contém os fólios de Windsor não publicados anteriormente (Leonardo da Vinci, 1911-16).

Moeller publicou, em 1930, um fólio de uma coleção em Weimar que possivelmente pertenceu ao volume organizado por Leoni, e existem outros fólios e esboços soltos de anatomia, como, por exemplo, no caso de dois fólios do Codice Forster III. Existem três outras edições do corpus de estudos de anatomia. A primeira foi feita por O'Malley e Saunders (1952) e ainda se encontra disponível, tendo recebido reimpressões em 1982, 1983, 1997 e 2003. A segunda está na edição do catálogo de desenhos de Windsor feita por Clark e revisada por Pedretti (1969). A terceira foi feita por Keele e Pedretti em 1978-80 e 1980-85, sendo a atual edição de referência. No terceiro volume dessa edição, estão citados e comentados os demais estudos de anatomia de Leonardo da Vinci, os quais consistem, em sua maior parte, em pequenos esboços em fólios que tratam de matérias diversas.

O conjunto de fólios que aqui se apresenta é inédito em português e faz parte de um projeto de publicá-los integralmente, acompanhados de introduções e comentários. Na introdução a seguir, aponta-se em especial para a formação da "ciência visual" de Leonardo da Vinci, fruto de um contexto cultural específico no interior do qual se considera as matérias anatômicas aqui apresentadas. 
A ciência visual de Leonardo da Vinci...

\section{As Gî̂NGIAS, AS ARTES E A ANATOMIA}

O Renascimento foi um período marcado pela tradição aristotélica (Schmitt, 1983; Bianchi, 2007; Kuhn, 2009). Não obstante as diversas variações que ocorreram entre os séculos XII e XVI, como as classificações de Henry de Langenstein (cf. Steneck, 1975) e Angelo Poliziano (cf. Nanni, 2007), as definições e o quadro de saberes de um modo ou de outro derivados dos textos de Aristóteles foram presentes até o final do Renascimento.

Cita-se dois exemplos significativos. O primeiro é de Benedetto Varchi, humanista ligado aos Medici e ao contexto dos artífices florentinos. ${ }^{2}$ No prefácio da segunda de suas Duas lições sobre a pintura e escultura, escritas no ano de 154,6, Benedetto Varchi, "falando aristotelicamente", menciona os "cinco hábitos do intelecto". ${ }^{3}$ Varchi diz que o terceiro hábito "chama-se ciência, a qual não é outra coisa que o conhecimento das coisas universais, necessárias e, consequentemente, eternas, tidas mediante demonstração" (Varchi, 1859, p. 628). Pouco após, ele diz que, "segundo a definição do Filósofo, arte é um hábito de fazer com verdadeira razão" (p. 628-9).4 O segundo é do jesuíta Franciscus Toletus, cujo livro, Comentários com questões sobre a física de Aristóteles em oito livros, publicado em 1574, possui o mérito de resumir as tradições textuais gregas e latinas (cf. Wallace, 1988, p. 209-11). Toletus afirma que a filosofia era qualquer saber

2 Opta-se pela palavra "artífice" para traduzir "artefice". Evita-se assim os sentidos atuais do termo "artista" relacionados ao artista romântico em diante, o qual faz suas obras a partir de sua subjetividade. Desse modo, sugere-se ao leitor que considere o sentido de "artífice" em relação a Leonardo e seus contemporâneos, que faziam suas obras seguindo encomendas e contratos. Segue-se com isso a tradição latina presente no Renascimento.

3 A tradução de "hexis" por "abito" usada por Varchi segue a tradição latina. Tomás de Aquino diz que "ciência é hábito demonstrativo (habitus demonstrativus)" (Sententia Ethic., lib. 6 I, 3 n. 8), e arte é "hábito de fazer (habitus factivus) com verdadeira razão" (Sententia Ethic., lib. 6 I, 3 n. 13).

4 Varchi segue o quarto capítulo do livro sexto da Ética a Nicômaco, como ele próprio declara, no qual Aristóteles diz que arte (techne) é a "disposição de produzir com reto raciocínio" (Et. Nic., 104,0a) no mundo da geração e corrupção, e ciência (episteme) é a "disposição demonstrativa" (Et. Nic., 1039b) das causas e dos princípios necessários e eternos. Opta-se pela palavra "arte" para traduzir "techne". A tradução por "arte" tem o risco de sugerir aproximações com sentidos contemporâneos de arte, mas a citação de Aristóteles deixa claro seu sentido. Segue-se assim a tradução latina "ars", palavra que no Renascimento italiano foi traduzida por "arte”. Uma opção de tradução é "técnica”. Entretanto, essa palavra não existe nos textos do Renascimento. Entende-se que algumas artes - justamente aquelas hoje chamadas de artes, como a pintura e a escultura - começavam a ser diferenciadas das demais artes já no século xv (talvez até antes, como sugere a fama de Giotto descrita por poetas e cronistas no século xiv), mas só no final do século XvıII esse processo foi consolidado (cf. Kristeller, 1951, 1952). Assim, preserva-se a variedade de produções em relação ao termo "arte": ao ler as biografias de Brunelleschi, Ghiberti, Martini e Leonardo, vê-se que eles (e tantos outros mais) faziam pinturas, esculturas, bandeiras para torneios, cúpulas, pontes, armas de guerra etc. Entende-se também que existem as disciplinas chamadas "história da técnica" e "história da arte", mas é possível aqui não remeter a disciplinas alheias ao Renascimento. Nesse sentido, usa-se "artífice" ao invés de "artista", como anotado na nota anterior, embora se saiba que hoje não é possível falar da fabricação de máquinas e a construção de canais dentro da disciplina chamada "história da arte". 
organizado por princípios e tinha por objetivo tirar o homem do estado de ignorância resultante do pecado original, particularmente em três áreas: na contemplação da verdade, no ensinamento da vida justa e no aprendizado de como manter a vida. Para Toletus, as três principais divisões da filosofia (philosophia) eram a especulativa (speculativa), a prática (practica) e a produtiva (factiva). Destas, a primeira era subdividida em metafísica, matemática e física. ${ }^{5}$ A metafísica estudava os princípios mais comuns de todo ser; a matemática, por sua vez, era subdividida em matemática pura, que estudava as entidades que não dependiam do movimento e dele eram abstraídas, e a matemática média, que estudava as entidades abstraídas ainda encontradas em movimento; a física especulava a respeito dos sensíveis. A filosofia prática era relacionada às ações e à condução da vida humana, e entre suas partes estavam a ética e a política. A filosofia produtiva estava voltada às produções e era dividida nas artes que eram necessárias à vida humana, aquelas que eram úteis e aquelas que proporcionavam contentamentos (cf. Wallace, 1988, p. 210-1). ${ }^{6}$ Essas definições estavam organizadas em uma hierarquia segundo a qual quanto mais afastado dos sentidos e das utilidades era um saber, mais elevado ele era. De fato, as universidades da época estavam comprometidas, sobretudo, com a filosofia teórica, e pouca ênfase era dada às filosofias prática e produtiva (cf. Wallace, 1988, p. 213).

$\mathrm{Na}$ busca de saberes relevantes para a sociedade em processo de progressiva mudança, as disciplinas práticas cabiam aos humanistas. Autores como Francesco Petrarca, Coluccio Salutati e Giannozzo Manetti escreveram a respeito de saberes úteis para a vida e louvaram as disciplinas morais e as artes de modo inédito (cf. Vasoli, 1988; Garin, 1994; Leinkauf, 2006). O currículo desses novos homens, os humanistas, chamava-se studia humanitatis, e seus estudos compreendiam a grammatica, a rhetorica, a poetica, a historia e a philosophia moralis (cf. Kristeller, 1988). Dotados das artes da palavra, eles exerciam papeis diversos, tais como o de professor em escolas para a aristocracia, ou ocupavam cargos políticos, como no caso de Salutati, que foi chanceler de Florença durante trinta anos. Segundo Garin (1994, p. 25), o humanismo "teve sua cátedra mais importante no Pallazo dei signori de Florença”. O novo valor da vita activa é mostrado de modo eloquente por duas pinturas. A primeira, do círculo de Bernardo

5 Também chamada de filosofia ou ciência natural (cf. Wallace, 1988, p. 202). Considera-se esse uso quando se escreve a palavra "ciência" nas páginas a seguir.

6 Toletus segue o primeiro capítulo do livro sexto da Metafísica (1025b-1026a), no qual a filosofia está dividida em ciência teórica (theoretiké), que incluía a filosofia primeira, a matemática e a física, ciências buscadas "segundo si mesmas”; ciência prática (praktiké), que incluía a ética e a politica, buscadas sobretudo para a condução da vida humana; e ciência produtiva (poietiké), que incluía a medicina, a retórica, entre outras, ou seja, as artes (technai) voltadas às necessidades e aos divertimentos. Ciência, nesta passagem, refere-se agora, de modo amplo, a conhecimentos organizados por princípios, daí ciência ser sinônimo de arte. 
Daddi, pintor da escola de Giotto, descreve Florença por volta de 134, e mostra uma cidade medieval de ruas e prédios sobrepostos (ver fig. 1). A segunda, de um pintor florentino anterior a 1500 , descreve uma cidade ideal tal qual era concebida por volta

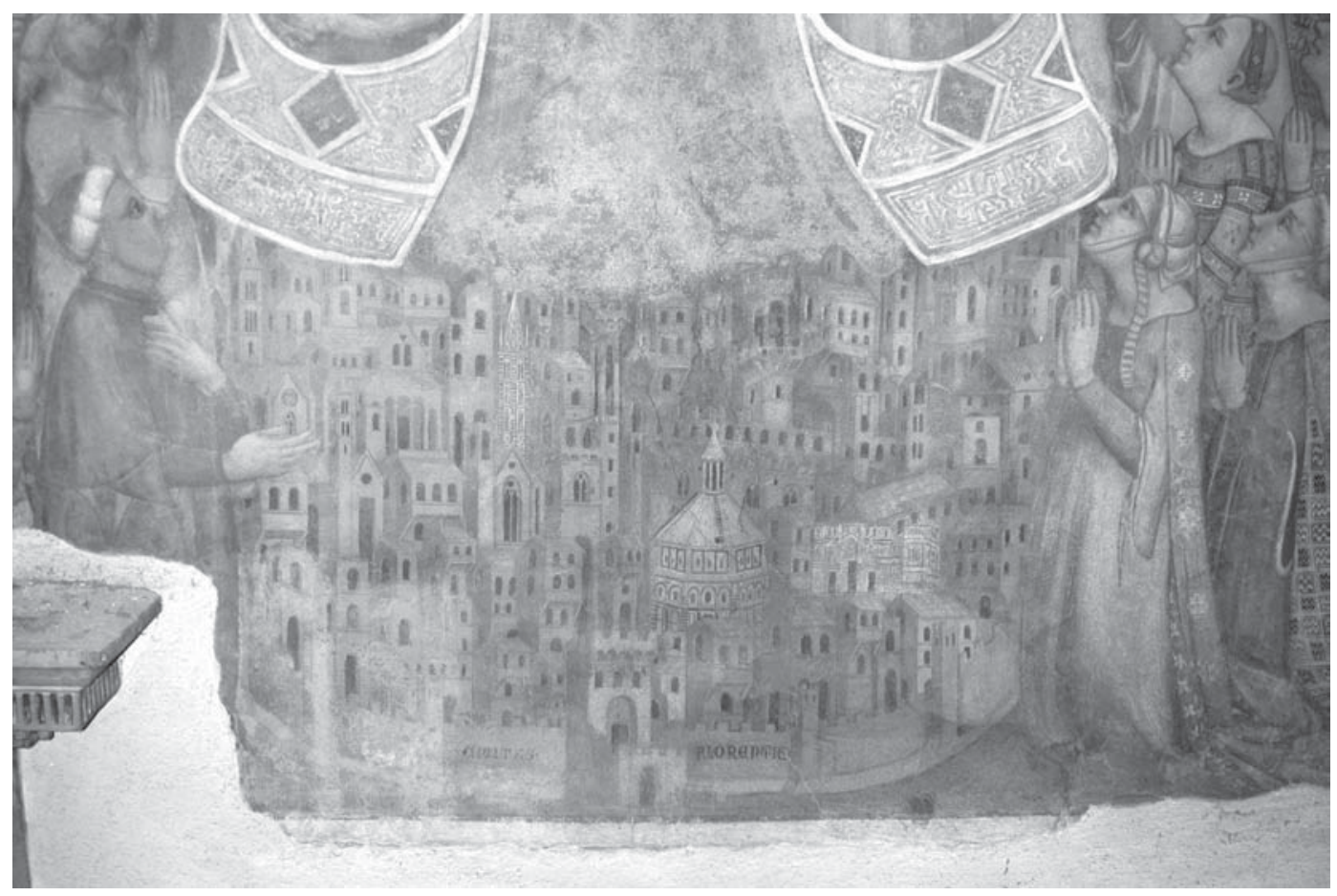

Figura 1. Círculo de Bernardo Daddi. Madonna da Misericórdia (detalhe mostrando Florença). Afresco, 1342. Loggia del Bigallo, Florença. Fonte: Giannozzo Pucci. Disponível em: <www.umilta.net/ bigallo.html >. Esta é a primeira vista conhecida da cidade de Florença. Pode-se ver ao centro o Batistério de São João Batista, cuja importância já era central para os florentinos na época, a Basílica de Santa Maria del Fiore e o Campanário, ambos em construção. Não obstante planta original romana, a cidade é mostrada sem urbanização evidente.

dessa época (ver fig. 2). Nessa pintura, pode-se ver uma cidade ordenada segundo as noções de urbanismo da Antiguidade, vindas, sobretudo, do texto de Vitrúvio, redescoberto no início do século xv por Poggio Bracciolini, e renovadas pelo humanista Leon Battista Alberti, entre outros. Em um contexto de progressiva valorização da vita activa, estava em questão a nova dignidade do homem, em parte alcançável por meio de suas artes.

Nesse contexto, as disciplinas produtivas cabiam aos artífices, que também tinham sua própria forma de transmissão de saberes. Nos ateliês, ocorriam aplicações inéditas das ciências em artes específicas como a pintura e a escultura, artes até então pouco sistematizadas, ao menos em relação aos poucos tratados antigos então conhe- 


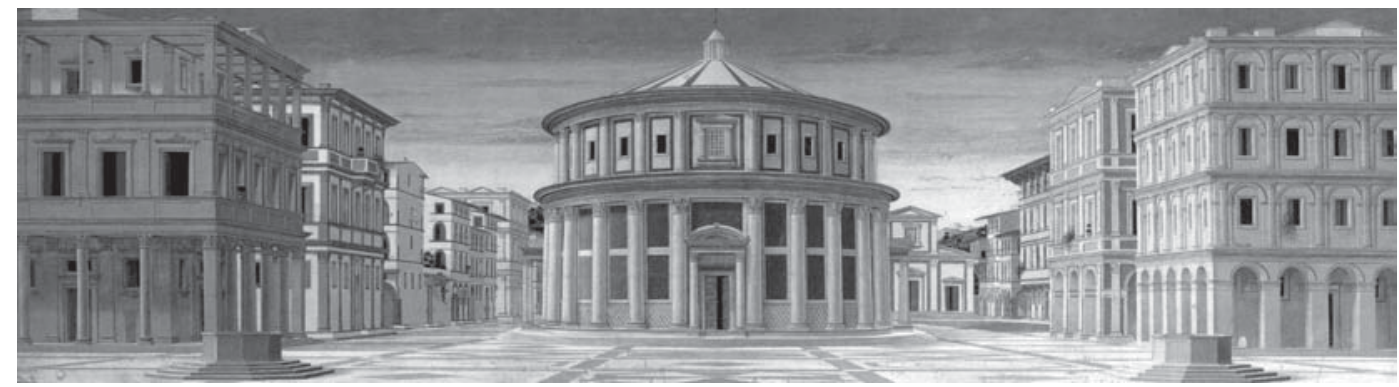

Figura 2. Artífice florentino. Cidade ideal. Têmpera sobre madeira, 60 x $200 \mathrm{~cm}$, circa 1500 . Galleria Nazionale, Urbino. Fonte: Web Gallery of Art. Disponível em: 〈www.wga.hu〉. Esta pintura mostra de modo claro o impacto da Antiguidade sobre os homens do Renascimento, especialmente se comparada com o afresco anterior. A aplicação de princípios de ordem e proporção são mostrados de modo evidente, seja no planejamento urbano da cidade, seja na aplicação da perspectiva à pintura.

cidos. O primeiro tratado que anuncia a progressiva valorização da arte da pintura é O livro da arte. Seu autor, o pintor Cennino Cennini, vinha de uma respeitada linhagem de artífices, como ele próprio afirma:

como pequeno membro em exercício na arte de pintar, nascido Cennino di Andrea Cennini da Colle di Valdelsa, fui instruído na dita arte durante doze anos por Agnolo di Taddeo de Florença, meu mestre, o qual aprendeu a dita arte de Taddeo seu pai, o qual, por sua vez, foi instruído por Giotto, e foi seu discípulo durante vinte e quatro anos (Cennini, 1859, cap. 1).

Cennini escreveu seu livro em Pádua por volta de 1390 , e pouco se conhece obras suas, não obstante toda a prática que ele mostra conhecer (cf. Boskovits, 1973). Seu texto começa, literalmente, do princípio:

No princípio, Deus onipotente criou o céu e a Terra, sobretudo animais e de outro modo, também criou o homem e a mulher à sua própria imagem, dotando-os de todas as virtudes. Depois, pelo inconveniente da inveja que veio de Lúcifer a Adão, aquele com malícia e sagacidade enganou este com o pecado contra as ordens de Deus, isto é, [enganou] Eva, e após Eva [enganou] Adão. E este Deus se zangou contra Adão e, por via de um anjo, Ele fez cair ele e sua companheira para fora do Paraíso, dizendo a eles: porque desobedecestes a ordem que Deus vos dissera, pelo vosso trabalho e exercício fareis a vossa vida. Conhecendo Adão o sobre o muro, isto é, em afresco, e de colorir ou encarnar um olhar juvenil” (cf. Cennini, 1859, cap. 67). 
A ciêngia visual de Leonardo da Vinci...

erro por ele cometido e sendo dotado nobremente por Deus, raiz, princípio e pai de todos nós, sabia de sua ciência (scienza) acerca da necessidade que tinha de encontrar um modo de viver manualmente, e, assim, ele começou com a enxada e Eva, com o tear. Após, seguiram muitas artes necessárias e diferenciadas umas das outras, e foram de maior ciência umas que outras, de modo que todas não podiam ser iguais, porque a mais digna é a ciência (Cennini, 1859, cap. 1).

Cennini aponta para a hierarquia de saberes do período. A primeira ocorrência da palavra "ciência" é genérica e tem o sentido de conhecimento comum; a segunda ocorrência está relacionada à palavra "arte" e sugere o sentido aristotélico de arte; e a terceira, de conhecimentos sistematizados por princípios. Cennini expressa o conceito de arte associado à necessidade, mas também aponta logo a seguir para uma arte que tinha uma relação inédita com a ciência, embora em uma relação de subordinação: "Junto daquela [a ciência] seguiu uma [arte] descendente daquela, a qual convinha ter fundamento naquela das operações manuais: e esta arte se chama pintar" (Cennini, 1859, cap. 1). Entretanto, Cennino não desenvolveu esse argumento, no sentido de explicitar qual era a ciência que o pintor tinha de saber, e escreveu que os fundamentos da arte de pintar estavam em suas operações manuais:

O fundamento da arte, e de todos esses trabalhos manuais, é o desenho e o colorir. Estas duas partes requerem isto, isto é: saber triturar ou macerar, colar, colocar telas, engessar, raspar os gessos e poli-los, modelar em gesso, colocar selos, colocar o ouro, brunir, temperar, destacar, polvilhar, raspar, estampar ou marcar, retalhar, colorir, adornar e envernizar em tábua ou retábulo. Trabalhar sobre muro, [e] necessita [saber] banhar, esmaltar, polir, desenhar, colorir a fresco, esboçar a seco, temperar, adornar, finalizar o muro. E esta sim é a regra dos graus ditos, sobre os quais eu, com aquele pouco saber que aprendi, direi aos poucos (Cennini, 1859 , cap. 4).

O texto de Cennini pertence a um âmbito produtivo e seus capítulos tratam de materiais de desenho, cores e colorir; de pincéis, da pintura mural e da pintura sobre painéis, de operações diversas como manufatura de miniaturas, de pintura sobre vidro etc. Cennini também apresenta breves capítulos a respeito da perspectiva (cf. Cennini, 1859, cap. 87) e das "medidas [que] deve ter o corpo do homem feito perfeitamente", no qual ele diz que "tem o homem uma costela a menos do que a mulher no lado esquerdo" (cf. Cennini, 1859, cap. 70), mostrando assim não ter conhecimentos de anatomia. Além disso, vivendo no culto ambiente de Pádua (cf. Bolland, 1996), Cennini sugere conhecer as discussões que visavam equiparar os pintores aos poetas: 
Convém [ao pintor] ter fantasia nas operações manuais, de encontrar coisas não vistas (fazendo-as sob a sombra do natural) e firmá-las com a mão, dando a demonstrar aquilo que não é, que venha a ser. E com razão [a pintura] merece ser colocada sentada em segundo lugar após a ciência e ser coroada de poesia. A razão é esta: porque o poeta, com a ciência primeira que tem, é digno e livre para poder fazer compor e ligar junto sim e não como lhe agrada, segundo sua vontade. Semelhantemente, ao pintor é dada liberdade para poder compor uma figura reta que está a sentar-se, meio homem e meio cavalo, segundo lhe agrada, segundo sua fantasia (Cennini, 1859 , cap. 1).

Cennini deixa claro que o artífice, tendo fantasia, compunha suas figuras buscando imitar a natureza de modo semelhante aos poetas. De fato, os artífices como ele começavam a almejar o estatuto das letras e das ciências, e a valorização de suas artes era acompanhada pelo decoro do pintor:

A tua vida deve ser sempre ordenada como se estivesses a estudar a teologia, a filosofia ou outras ciências, isto é, comer e beber moderadamente ao menos duas vezes ao dia, usando pratos leves e de valor, bebendo pequenos vinhos, conservando e retendo a tua mão, guardando-a dos trabalhos como jogar pedras, estacas de ferro e muitas outras coisas que são contrárias à mão (Cennini, 1859, cap. 29).

Em poucas palavras, em um texto que expressa os conhecimentos que circulavam nos ateliês dos pintores, Cennini aponta para as doutrinas e as teorias do século $\mathrm{XV}$, as quais visavam a elevação do status social dos artífices. A dignidade do homem também ocorria através de suas artes, inclusive a arte da pintura.

Por volta de 14,10, Filippo Brunelleschi aplicou a geometria à pintura, inventando a perspectiva geométrica para uso dos artífices. $\mathrm{O}$ afresco Trindade de Masaccio está entre os primeiros exemplos existentes (ver fig. 3). Brunelleschi não era letrado, ao menos no sentido dos studia humanitatis, de modo que coube a Leon Battista Alberti sistematizar a perspectiva em seu tratado Da pintura, escrito em $1_{4} 3_{5}$ em latim e traduzido por ele próprio para o italiano no ano seguinte. Alberti dedica o primeiro livro à perspectiva brunelleschiana, adicionando outras ciências como a anatomia, mencionada após a mensuração dos membros das figuras: "primeiro, o pintor colocará cada osso do animal em sua posição, e após seus músculos e então suas carnes" (Alberti, 1973, cap. 36). Seu objetivo era expressar "os movimentos do ânimo" que eram "conhecidos pelos movimentos do corpo", ou seja, no contexto em que a pintura era concebida como discurso retórico, ela visava comover "o ânimo dos espectadores se os homens nela pintados manifestarem especialmente seu movimento do ânimo" (Alberti, 1973, 
Figura 3. Masaccio. Trindade. Afresco, $66_{7} \times 3_{17} \mathrm{~cm}$, circa $\mathbf{1 4}^{2} 25$. Santa Maria Novella, Florença. Fonte: Web Gallery of Art. Disponível em: 〈www.wga.hu〉. Trata-se da primeira pintura conhecida em que estão aplicados os princípios da perspectiva geométrica inventada por Brunelleschi por volta de 14,10. A arquitetura em que estão as figuras é brunelleschiana, e suspeita-se que o próprio Brunelleschi participou de sua elaboração. Na porção inferior, está escrito sobre o esqueleto: "Io fu ga quel che voi sete equel chison voi aco sarete." ("Eu já fui aquele que vós sois, $\mathrm{e}$ aquele que sou vós sereis.")

cap. 41). Alberti expõe um conjunto de conhecimentos sistematizados a partir "dos primeiros princípios da natureza" (Alberti, 1973, cap. 1) voltados a produzir, iniciando inclusive de modo euclidiano, isto é, definindo seus elementos básicos: ponto, linha etc.

Nessa época, o escultor Lorenzo Ghiberti também buscou sistematizar sua arte em um tratado conhecido como Os comentários. Sem a formação humanista de Alberti, Ghiberti não tinha cultura para finalizar um tratado. Seu tratado, de fato, é dividido em três partes. A primeira descreve os fundamentos das artes e a história de artífices da Antiguidade, sendo baseada nos textos de Plínio e Vitrúvio. A segunda parte é a história dos artífices de Giotto até ele próprio, sendo a contribuição mais importante do tra-

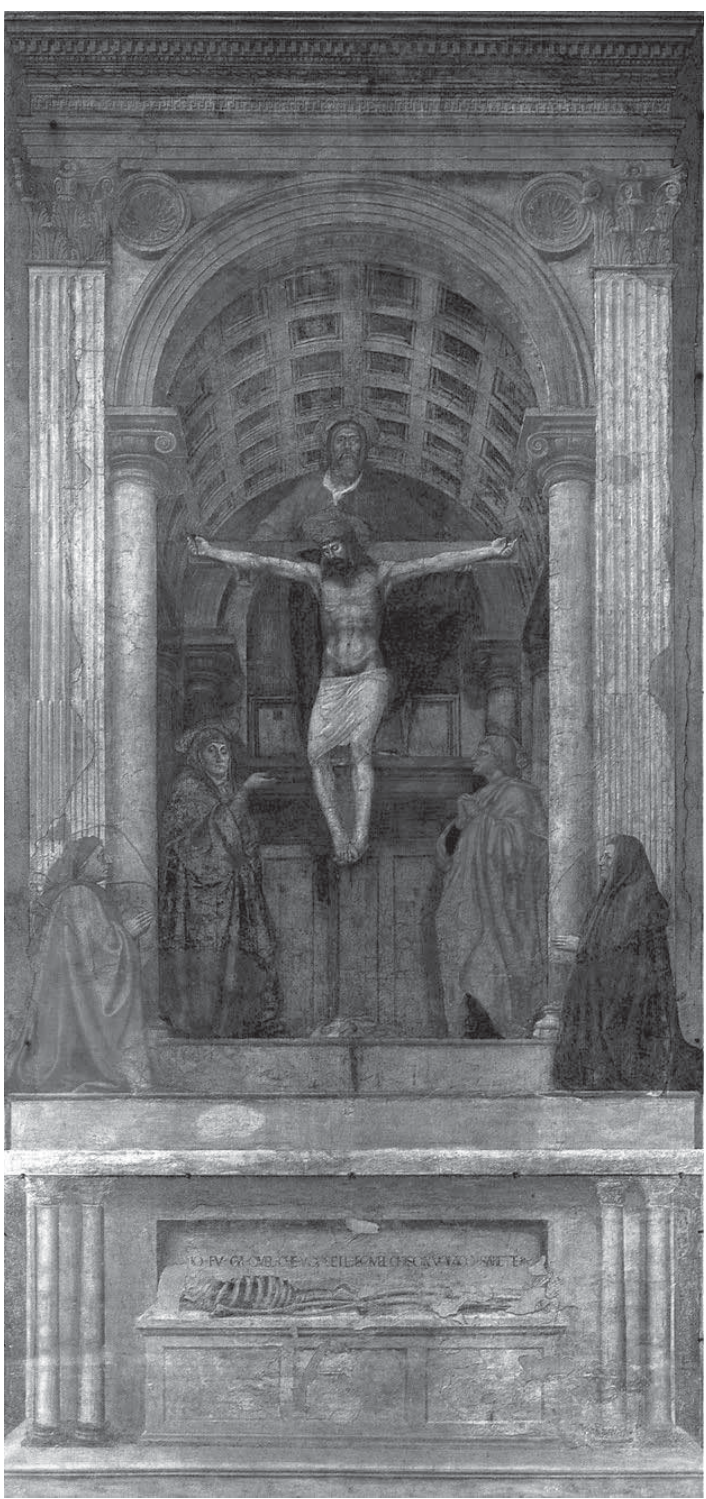
tado. A terceira é uma longa compilação de textos de filosofia natural, tendo a óptica como ponto central. O tratado não tem a organização do Da pintura e está inacabado. De qualquer modo, Ghiberti buscou em, sua primeira parte, organizar as disciplinas para a formação do "artífice perfeito":

E convém que letrado seja, perito em escritura e ensinado em geometria, e tenha conhecido muitas histórias ou escutado diligentemente filosofia, e que seja ensinado em medicina e tenha escutado astrologia, e que seja douto em perspectiva e ainda seja desenhista perfeitíssimo" (Ghiberti, 1998, I, cap. 2, § 4).

Ghiberti enfatiza (1998, I, cap. 2, §5) o conhecimento da matemática, isto é, a geometria de que Alberti escrevera, e menciona (1998, I, cap. 2, § ₹) a filosofia para fazer do escultor um artífice de "espírito generoso, de modo que não seja arrogante" e capaz de conhecer a "natureza das coisas", além de conhecer a medicina, como ele diz: 
Ainda necessita ter conhecido a disciplina da medicina e ter visto anatomias, de modo que o escultor saiba quantos ossos existem no corpo humano quando quer compor a estátua viril, e que saiba os músculos que existem no corpo do homem e, assim, todos os nervos e ligamentos que existem (Ghiberti, 1998, I, cap. $2, \S 8)$.

As disciplinas continuam com a astrologia, terminando assim os contornos gerais da formação do "artífice perfeito".

Cennini, Alberti e Ghiberti buscavam em diversas ciências e artes princípios para operar seguramente e dizer quanta ciência havia em suas artes específicas, elevando assim o estatuto de conhecimento das artes e seu próprio status social. Para obter isso, eles assumiam os sentidos tradicionais de arte e ciência, cada qual a seu modo. Cennino seguia a hierarquia aristotélica, sabendo o lugar da pintura, como citado acima: "E com razão [a pintura] merece ser colocada sentada em segundo lugar após a ciência e ser coroada de poesia" (Cennini, 1859, cap. 1). Alberti pede a seus leitores que considerem que ele não escrevia como matemático, mas como pintor, e que fazia uma "Minerva gorda" (Alberti, 1973, cap. 1), isto é, não uma sabedoria abstrata, mas uma sabedoria do mundo da geração e corrupção. Alberti, um pintor diletante de quem não se conhece pinturas, visava “as coisas postas ao ver" (Alberti, 1973, cap. 1). Ghiberti, por sua vez, escreve que as artes "são fabricadas com certa meditação, a qual se faz com matéria e raciocínios", e a ciência serve para que "as coisas fabricadas por proporção de astúcia e de razão" possam "ser demonstradas e explicadas" (Ghiberti, 1998, I, cap. $2, \S 2$ ). Seus interesses para com suas obras ficam claros ao mencionar de novo a anatomia necessária ao "artífice perfeito":

Não necessita ser médico como Hipócrates, Avicena e Galeno, mas bem necessita ter visto as obras deles, ter visto anatomias, ter por número todos os nervos e todos os ligamentos que existem na estátua viril; das outras coisas da medicina, não necessitamos tanto (Ghiberti, 1998, I, cap. 2, §10).

Nesse contexto de aceitação das noções tradicionais, vinham juntos o descaso e desprezo que existiam na cultura antiga (cf. Koyré, 1971). Por exemplo, não obstante os elogios que Alberti faz à pintura, ele deixa claro que a pintura convinha aos engenhos livres apenas nos momentos de ócio, ao dizer que pintava quando estava livre "de suas outras maiores atividades" (1973, cap. 28). Não era digno de um homem letrado como ele ganhar sua vida como artífice. Alberti aqui repete uma opinião de Luciano, citado por Kristeller (1951, p. 503) como a opinião corrente da Antiguidade: "todos admiram 
os trabalhos dos grandes escultores, mas não querem ser escultores". 8 Se não havia mais desprezo pelas artes, socialmente seu valor ainda era secundário para a aristocracia letrada.

Em suma, o quadro tradicional estava presente até no ambiente dos artífices, e eles faziam aplicações de artes e ciências em suas artes específicas. Manetti, em sua biografia de Brunelleschi escrita em torno de 1480, diz:

Aquilo que os pintores atualmente chamam de perspectiva é uma parte daquela ciência que é, de fato, [a ciência] de colocar bem e com razão as diminuições e crescimentos que aparecem aos olhos dos homens das coisas [que estão] longe e perto: construções, planícies, montanhas e paisagens de todo tipo e em qualquer lugar, as figuras e as outras coisas, com a medida que corresponde àquela distância em que elas se mostram de longe (Manetti, 1927, p. 9).

O estudo da perspectiva dos artífices do Renascimento era apenas uma parte de um corpus de conhecimento óptico muito amplo, cujos textos principais eram os de Alhazen, Peckham, Roger Bacon e Pelacano. Esse conhecimento óptico tinha por objetivo estabelecer corretamente as dimensões dos objetos aos olhos dos homens sobre uma superfície plana. Os artífices não tinham interesses em elaborar teorias.

No campo da medicina, o tratado Anatomia, escrito por Mondino dei Liuzzi por volta de 1316, introduziu a prática de dissecação. Entretanto, o descaso e o desprezo existentes contra as atividades manuais fizeram surgir a tradição textual no ensino da anatomia, segundo a qual um professor de anatomia lia o texto em latim e um cirurgião-barbeiro fazia a demonstração. Andreas Vesalius, no prefácio do Da estrutura do corpo humano, publicado em 1543, diz que ainda existia então "o detestável procedimento agora em voga, no qual um homem faz a dissecação do corpo humano e outro lê a descrição das partes" (ver fig. 4). Desse modo, a anatomia, "o ramo central da filosofia natural”, foi vítima de um "odioso naufrágio":

8 A elevação do status social dos pintores, dos escultores e dos arquitetos nos séculos xv e xvı é conhecida, especialmente ao se pensar a respeito de Leonardo da Vinci, Michelangelo e Rafael, entre outros. Entretanto, apenas na passagem do século xviı para o XIX surgiu o artista como hoje se conhece. No caso das mecânicas, Galluzzi (1987) e Rossi (2001) mostram o crescente status social dos engenheiros no Renascimento. Entretanto, Rossi (2001, p. 4,1) cita o Da natureza metálica de Georg Bauer, o mais conhecido tratado técnico do Renascimento, e diz que a arte dos metais era considerada "indigna e vil”. Rossi (2001, p. 42) também cita a obra Livros de mecânica de Guidobaldo del Monte, publicada em 1577, na qual Guidobaldo diz que em muitas partes da Itália "costuma-se apelidar alguém de mecânico por escárnio e insulto, e alguns ficam irritados por serem chamados de engenheiros", e logo após defende o novo saber do "engenheiro", palavra que designa um "homem de alta competência, que por meio das mãos e do engenho sabe executar obras maravilhosas". Ao lado de feitos relacionados à navegação, aos moinhos a vento, à imprensa e tantos outros mais, havia ainda, por parte de certos contextos sociais, resistência às mecânicas. 
Estes últimos ficam empoleirados em um púlpito como macacos, e com um notável ar de desdém, eles jogam informações a respeito dos fatos de que nunca se aproximaram em primeira mão, mas que meramente dizem de memória dos livros de outros, ou dos quais leem descrições que têm em frente a seus olhos. Os primeiros são tão ignorantes em línguas que são incapazes de explicar suas dissecações aos observadores e apontar ao que deveria ser exibido segundo as instruções do médico, que nunca coloca sua mão na dissecação, e desprezivelmente governam o navio fora do manual, como se diz. Assim, tudo é erroneamente ensinado, dias são gastos em questões absurdas e, na confusão, menos é oferecido ao observador do que seria por um açougueiro que, em seu açougue, poderia ensinar um doutor (Vesalius, 1958, p. 522-3).

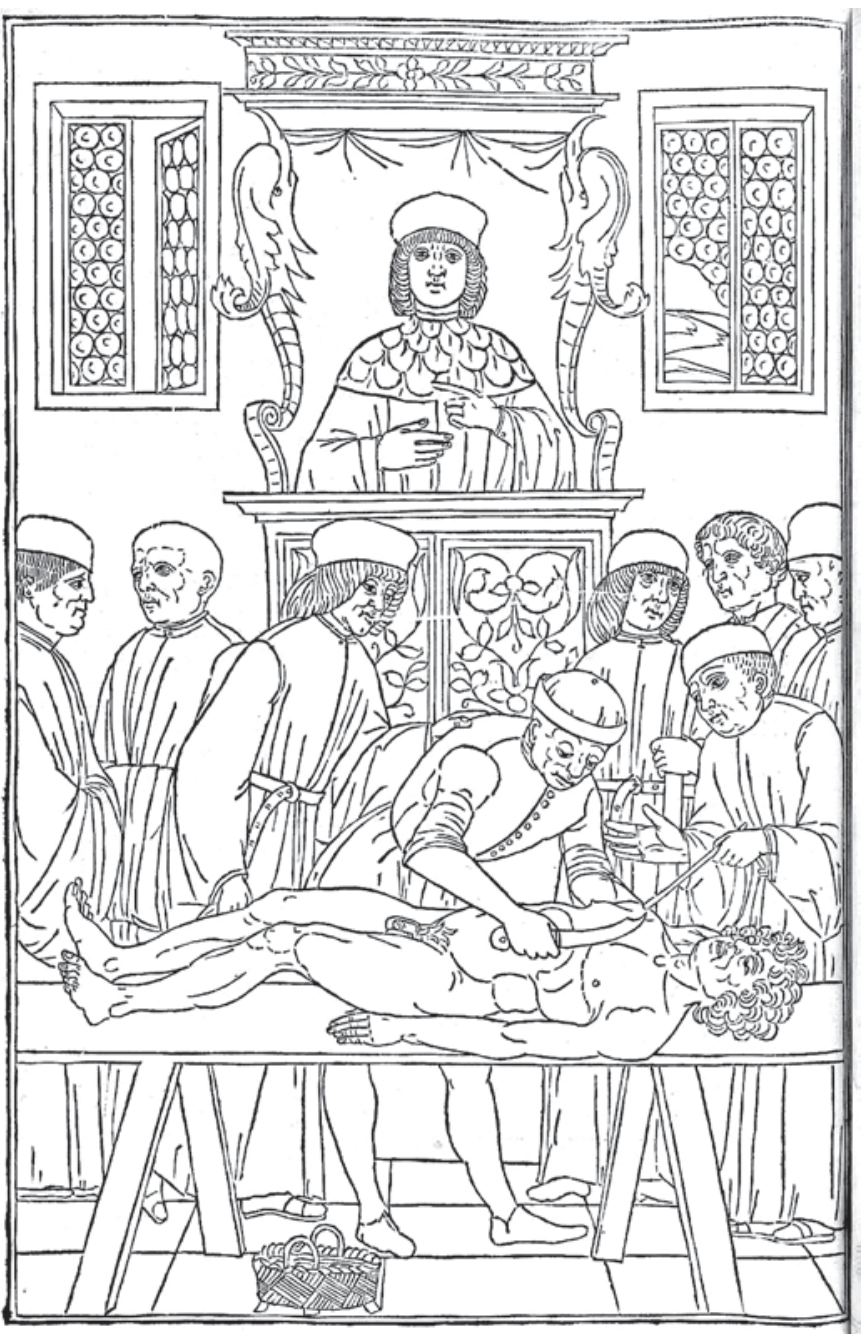

As dissecações não tinham o objetivo de corrigir os textos da tradição nem servir como investigações independentes, mas no máximo confirmar suas doutrinas e teorias. Entretanto, o Renascimento mostra a passagem de uma cultura de memória e instrução para uma cultura de descoberta e invenção (cf. Park, 1998). Em outras palavras, havia tensões entre a autoridade e a experiência, esta associada às operações manuais consideradas indignas, aquela aos

Figura 4. Artífice veneziano anônimo. Ilustração do Fasciculus medicinae de Johannes de Ketham (Venezia: Zuane \& Gregorio di Gregorii, 1493, p. 64). Xilogravura, 32 x 22,5 cm. National Library of Medicine, Bethesda. Fonte: National Library of Medicine: Historical Anatomies on the Web. Disponível em: <www.nlm.nih.gov/exhibition/historicalanatomies/ home.html >. O Fasciculus medicinae é uma coleção de seis textos medievais que circulou por volta de 14,00 e foi editada em latim em 1491, com diversas edições sucessivas. Entre esses textos, está o Anothomia mundini, editado por Pietro Andrea Morsiano, e textos a respeito da astrologia e da prática de venesecção, entre outros. Về-se, na gravura ao lado, o procedimento usual das universidades do Renascimento, conforme descrito por Vesalius. 
A ciência visual de Leonardo da Vinci...

Figura 5. Estúdio de Tiziano. Página-título da obra, De humanis corporis fabrica, de Andreas Vesalius (Basileae, Joannes Oporinus, ${ }_{154^{3}}$ ). Xilogravura, $4^{3}$ $x{ }_{27} \mathrm{~cm}$. National Library of Medicine, Bethesda. Fonte: National Library of Medicine: Historical Anatomies on the Web. Disponível em: <www.nlm. nih.gov/exhibition/historicalanatomies/home. html>. O livro de Vesalius é o primeiro que empregou de modo sistemático gravuras, possivelmente feitas em torno do ateliê de Tiziano Veccelio, o grande pintor veneziano do século XVI. Vê-se na gravura acima o próprio Vesalius dissecando, contrariando assim o procedimento usual mostrado na gravura anterior.

textos dos antigos. Coube a Vesalius descer da cátedra para expor a anatomia do homem (ver fig. 5). Nesse contexto, a anatomia era uma ciência, e como ciência tinha de ser discursiva. O texto de Mondino não é ilustrado, assim como o texto de Hieronymo Manfredi, também chamado Anatomia, es-

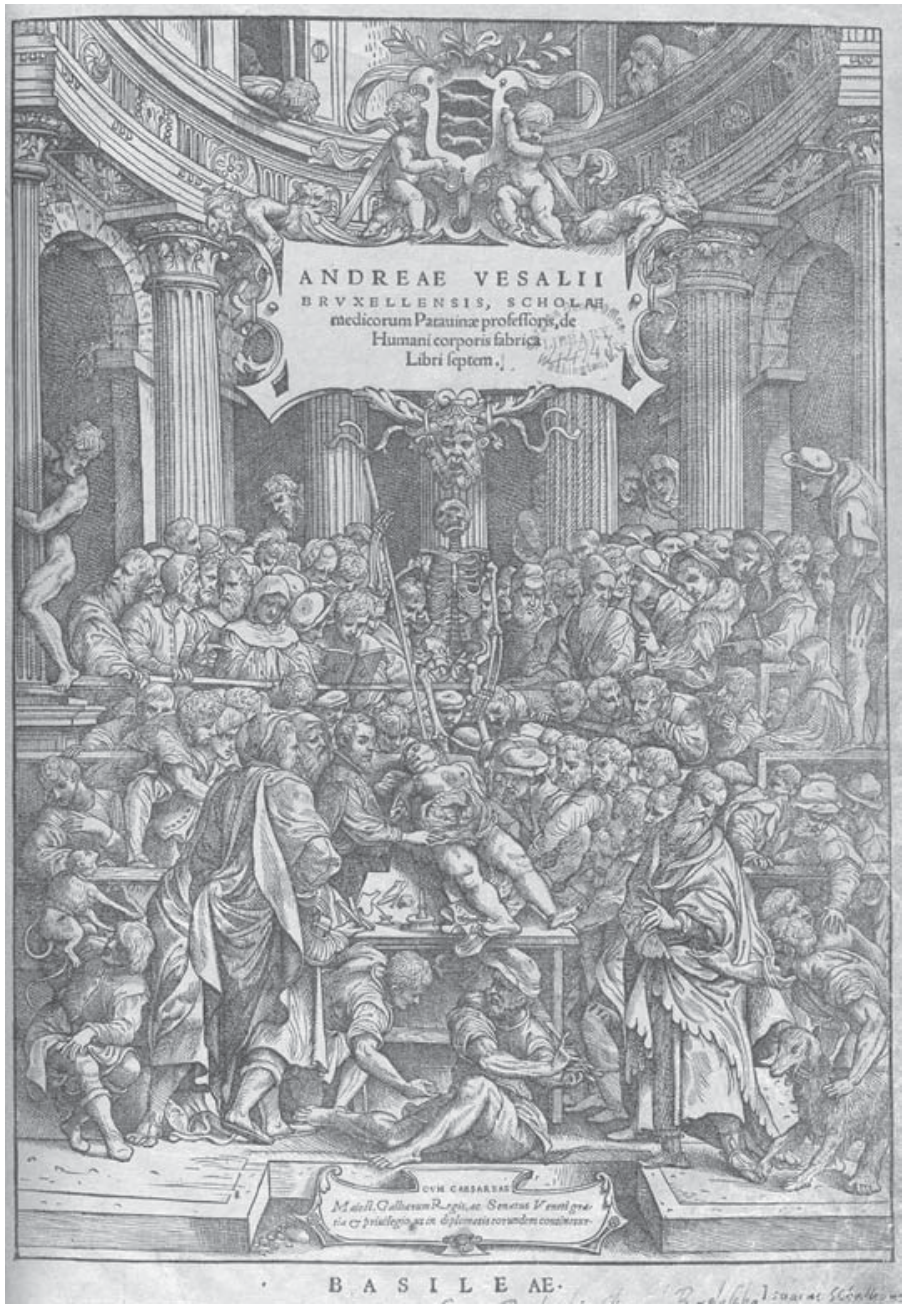
crito em Bolonha por volta de 1490. A rudeza das ilustrações do período anterior a Vesalius mostra o pouco interesse pelas artes dos artífices por parte dos professores de anatomia (ver fig. 6). A inclusão de gravuras nos tratados de anatomia ocorreu aos poucos, e inclusive Vesalius teve de enfrentar resistências por utilizá-las em seu grande livro de 1543.9

\section{LeONARdo da Vingi e a ANATOMia do homem}

$\mathrm{Na}$ época dos tratadistas citados acima, havia pouco interesse pela figura humana nua como forma principal de ser representada em uma pintura ou escultura. A pintura de Masaccio mencionada acima (ver fig. 3) é uma das poucas do período que mostram um corpo nu (e também um esqueleto na parte de baixo). A figura humana só começou a ser objeto central de pinturas e esculturas por volta de 1470 na obra de pintores como

9 Uma coleção significativa de imagens em alta definição dos tratados de Johannes de Ketham, Magnus Hundt e Berengario da Carpi pode ser vista na página HistoricalAnatomies on the Web: <www.nlm.nih.gov/exhibition/historical anatomies/home.html>. 


\section{(ifiguth de fitu uifretum.}

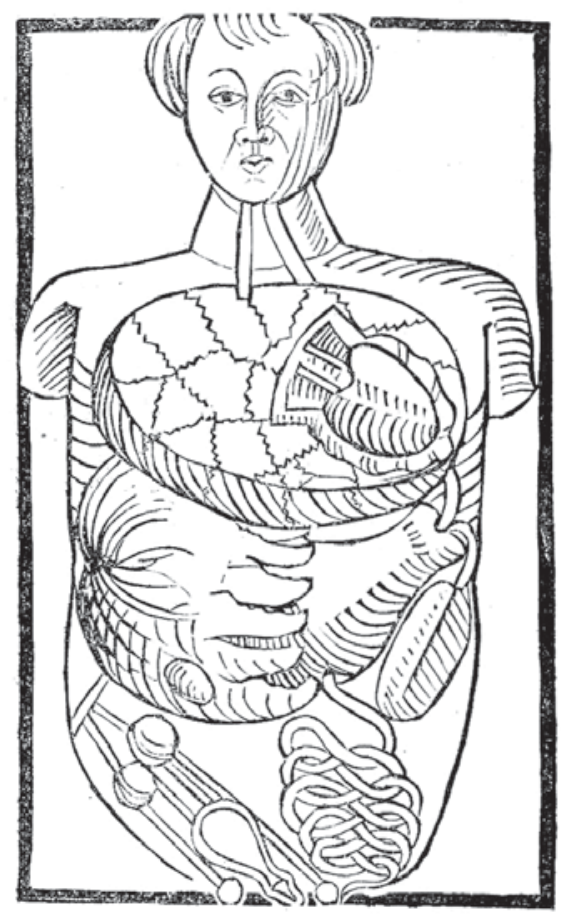

Figura 6. Artífice anônimo. Ilustração dos órgãos internos, que se encontra no Antropologium, de hominis dignitate natura et proprietatibus de Magnus Hundt (Leipzig: Wolfgangum Stöckel, 1501. p. 119). Xilogravura, 22 x 15,5 cm. Fonte: National Library of Medicine: Historical Anatomies on the Web. Disponível em: <www.nlm.nih.gov/exhibition/ historicalanatomies/home.html>. O Antropologium, escrito pelo médico e teólogo Hundt, visa explicar não apenas a constituição do homem, mas também seus aspectos filosóficos e religiosos. A rudeza da ilustração sugere seu uso apenas como ajuda à memória. É importante notar que Leonardo da Vinci fez seus desenhos do crânio humano mais de dez anos antes dessa publicação.

Antonio del Pollaiolo, de quem Vasari diz que "entendeu dos nus mais modernamente do que os outros mestres antes dele" e que ele "anatomizou muitos homens para ver a anatomia deles, e foi o primeiro a mostrar o modo de desenhar os músculos que tinham forma e ordem nas figuras" (Vasari, 1822, II, p. 436-7) (ver fig. 7). Essa opinião é plausível, embora não existam desenhos de anatomia feitos por artífices anteriores aos desenhos de Leonardo da Vinci.

Leonardo formou-se no ateliê de Andrea del Verrocchio, no qual aprendeu as artes para a realização de pinturas e esculturas. Seguindo o contexto de sua época, a ênfase da formação de Leonardo estava no desenho. ${ }^{10}$ De fato, desde Vasari, Leonardo é considerado o artífice que iniciou a "terceira maneira" do Renascimento italiano. ${ }^{\mathbf{1 1}}$

10 A ênfase no desenho começou com Cennini (1859, cap. 4), que chama o desenho de "fundamento da arte", como referido acima, tradição seguida por Alberti, Ghiberti e pelo próprio Leonardo. O substantivo italiano "disegno", traduzido em português por "desenho", tem dois sentidos principais: o sentido de um objeto feito com materiais como ponta de prata, pena e nanquim ou sanguínea, especialmente sobre papel, como um desenho de Leonardo da Vinci, e o sentido de uma forma elaborada a partir de raciocínios, como ao se dizer "o desenho de uma Ferrari". Como sugerido, o português também tem esses sentidos, embora o primeiro seja mais concreto e imediato do que o segundo. A língua inglesa deixa claro essa distinção ao traduzir "disegno" tanto por "drawing" quanto por "design". 11 Após comentar os artífices anteriores a Leonardo, Vasari escreveu (1822, II, p. 436-7): "mas os erros daqueles mais tarde foram demonstrados nas obras de Leonardo da Vinci, que, dando princípio à terceira maneira, que nós queremos chamar de moderna, além do vigor e do virtuosismo do desenho, e além de forjar sutilissimamente todas as minúcias da natureza feitas assim como elas são, com boa regra, melhor ordem, medida correta, desenho perfeito e graça divina, abundantíssimo em cópias e profundíssimo na arte, deu a suas figuras o movimento e o sopro de vida." 


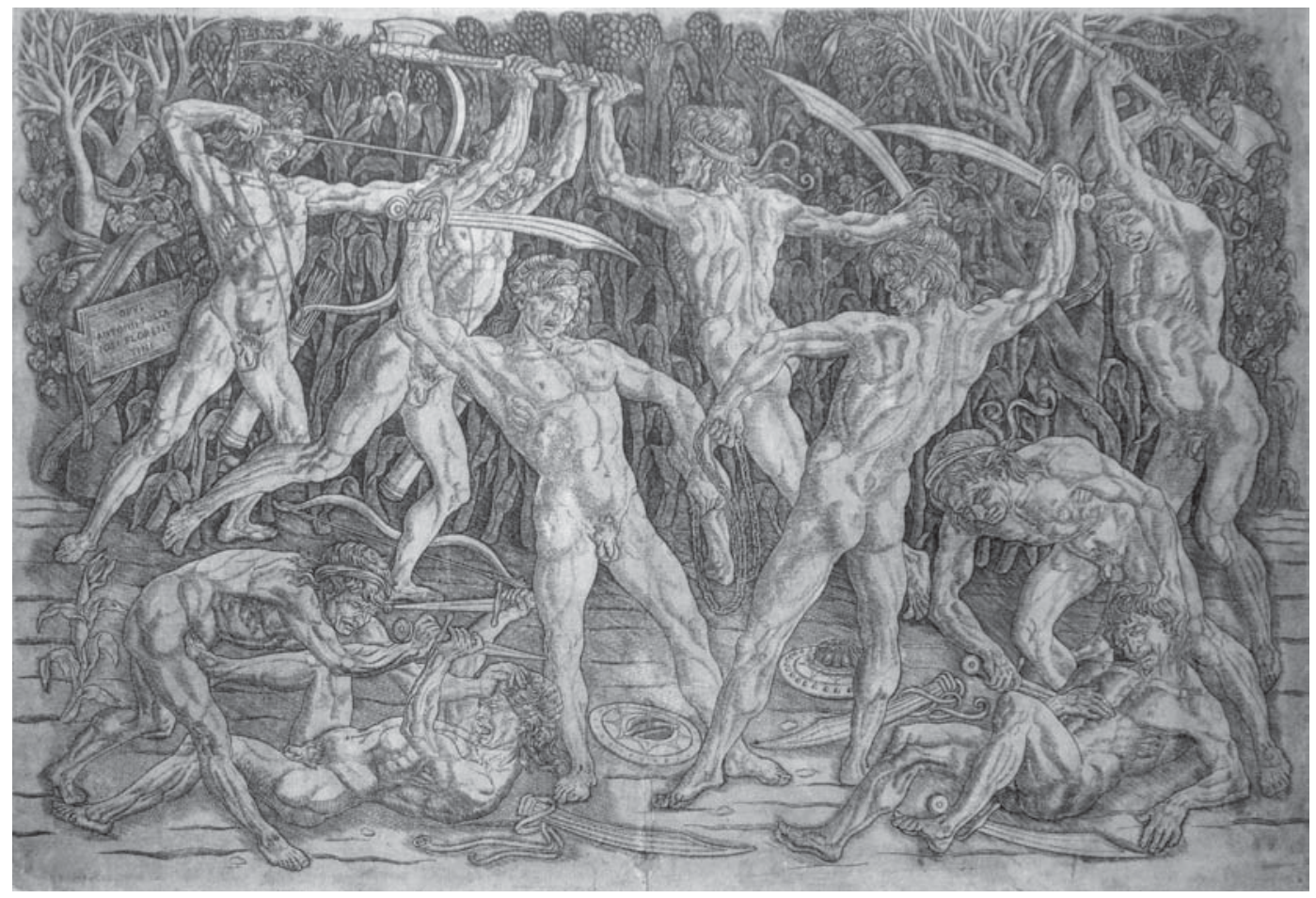

Figura 7. Antonio del Pollaiolo. A batalha dos dez nus. Buril, $\mathbf{4 2}_{\mathbf{2}}, \mathbf{8} \times \mathbf{6 1}, \mathbf{8} \mathbf{c m}$, circa $\mathbf{1 4 7}$. Galleria degli Uffizi, Florença. Fonte: Web Gallery of Art. Disponível em: 〈www.wga.hu〉. Essa gravura, cujo tema permanece desconhecido, parece ser, sobretudo, uma demonstração do engenho e da arte de Pollaiolo para representar figuras nuas, na época em voga na pintura florentina. Além de estudos de anatomia da superfície, as figuras sugerem conhecimento das esculturas romanas.

Seu engenho e sua arte de desenhar eram seus principais instrumentos para isso. Vê-se no Estudo de São João Batista uma graça nova em relação às obras de artífices contemporâneos, especialmente quanto ao tratamento naturalista da anatomia superficial da figura e a articulação entre seus membros (ver ilust. 1). O Estudo de panejamento mostra como Leonardo tratava de luzes e sombras, e o fólio de estudos aponta para a invenção do esboço (ver as ilust. 2 e 3). Leonardo sabia de sua invenção, como mostra a seguinte preceptiva do Livro de pintura, datada de aproximadamente 1492:

Preceptiva para compor histórias.

Ó tu que compões histórias, não articules com linhas precisas as partes individuais dessas histórias, pois acontecer-te-á como a muitos e variados pintores que querem que o menor sinal de carbono seja válido. E estes podem bem adquirir riquezas, mas não louvores na sua arte, porque muitas vezes o animal figurado não tem os movimentos de seus membros apropriados aos movimentos da men- 
te. E uma vez que eles tenham feito uma bela e finalizada articulação, a eles parecerá injurioso mudar a posição dos membros para cima ou para baixo, para frente ou para trás. Eles não são merecedores de algum louvor na sua ciência. Ou nunca considerastes os poetas compositores dos seus versos, dos quais não se cobra fazer belas letras, e nem eles se preocupam [com isso] quando rabiscam alguns de seus versos? Assim, pintor, compõe grosseiramente os membros das tuas figuras e cuides antes dos movimentos apropriados aos acidentes mentais dos animais que compõem a história do que da beleza e da perfeição dos seus membros (Leonardo da Vinci, 1995, cap. 189). ${ }^{\mathbf{1 2}}$

Gombrich (1966) analisou isso pela primeira vez, e Kemp (1996, p. 192) resume de modo claro o processo de desenhar de Leonardo:

Leonardo foi um dos mais inovadores e férteis desenhistas de todos os tempos. Em suas mãos, a prática do desenho tornou-se uma extensão de seu pensamento criativo, não apenas expressando uma série de novas ideias em abundante profusão, mas também tornando-se, através de uma rápida confusão de alternativas esboçadas sobrepostas umas sobre outras, um modo de permitir que as configurações ao acaso ajudassem o processo inventivo. O desenho tornou-se uma forma de pensamento visual mais do que um mero meio para desenhar uma pintura.

No ateliê de Verrocchio, Leonardo também aprendeu a perspectiva dos artífices, conforme mostra o Estudo de perspectiva para a Adoração dos Magos (ver ilust. 4). Se Leonardo fez o Estudo de São João Batista e o Estudo de panejamento a partir de observações de modelos, os esboços e o conhecimento da perspectiva permitiam a ele compor espaços e figuras de memória, isto é, de modo independente de observações dal naturale. Tendo esses tipos de desenho, Leonardo podia fazer composições como o Estudo para Madona com o menino e gato, no qual se vê um naturalismo inédito, no sentido da articulação entre os membros das figuras em vista da expressão de afetos em um espaço sugerido pelas próprias figuras (ver ilust. 5 ). Por fim, como parte de sua formação, Leonardo também aprendera a desenhar mecanismos e máquinas (ver ilust. 6). De fato, o ateliê de Verrocchio colocou em 14,69 a primeira esfera de bronze sobre a lanterna do Duomo de Florença, na época em que Leonardo fazia parte desse ateliê.

12 Existem desenhos de Verrocchio semelhantes aos esboços de Leonardo (cf. Tofani, 1987, figuras 44,3e e 444,e), mas a inovação de Leonardo é evidente. Uma variante do parágrafo acima está no breve capítulo do Livro de pintura intitulado "Preceptiva a respeito do desenho ao esboçar histórias e figuras" (cf. Leonardo da Vinci, 1995, cap. 64). 


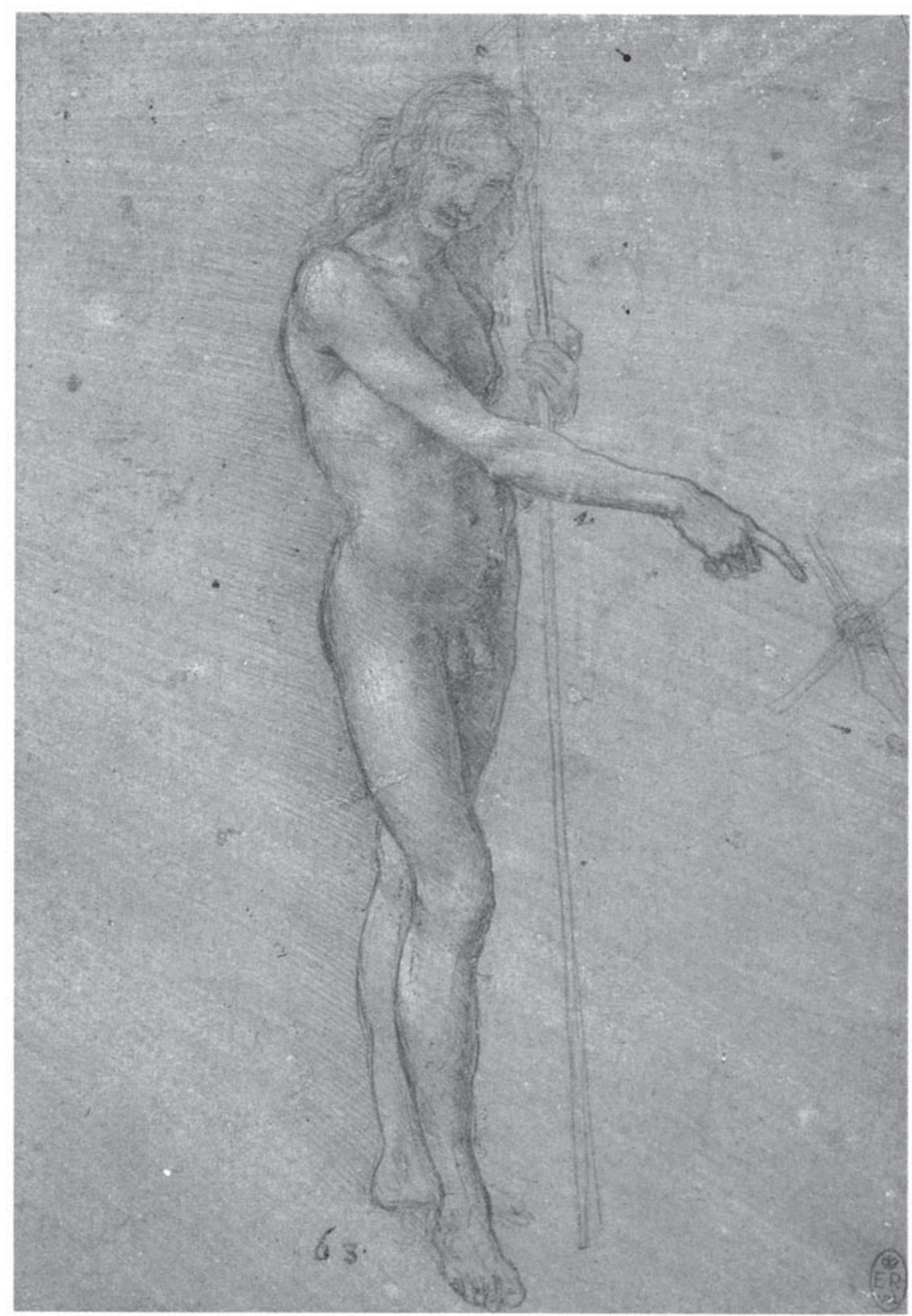

Ilustração 1. Leonardo da Vinci. Estudo para um São João Batista. Ponta de metal com retoques de branco sobre papel preparado em azul, 18,7 x 12,2 cm, circa 1478. Royal Library, Windsor. Fonte: KeмP, M. \& Roвевтs, J. Leonardo da Vinci. Artist - scientist - inventor. London: Yale University Press/South Bank Centre, 1989. As formas dos membros e a posição do santo mostram o engenho e a arte de Leonardo ao desenhar dal naturale, os quais fizeram Vasari colocá-lo como o iniciador do terceiro período do Renascimento. $O$ contraste com a gravura de Pollaiolo faz isso evidente. $O$ material empregado para desenhar, que não podia ser apagado, mostra também o virtuosismo do desenho de Leonardo. 


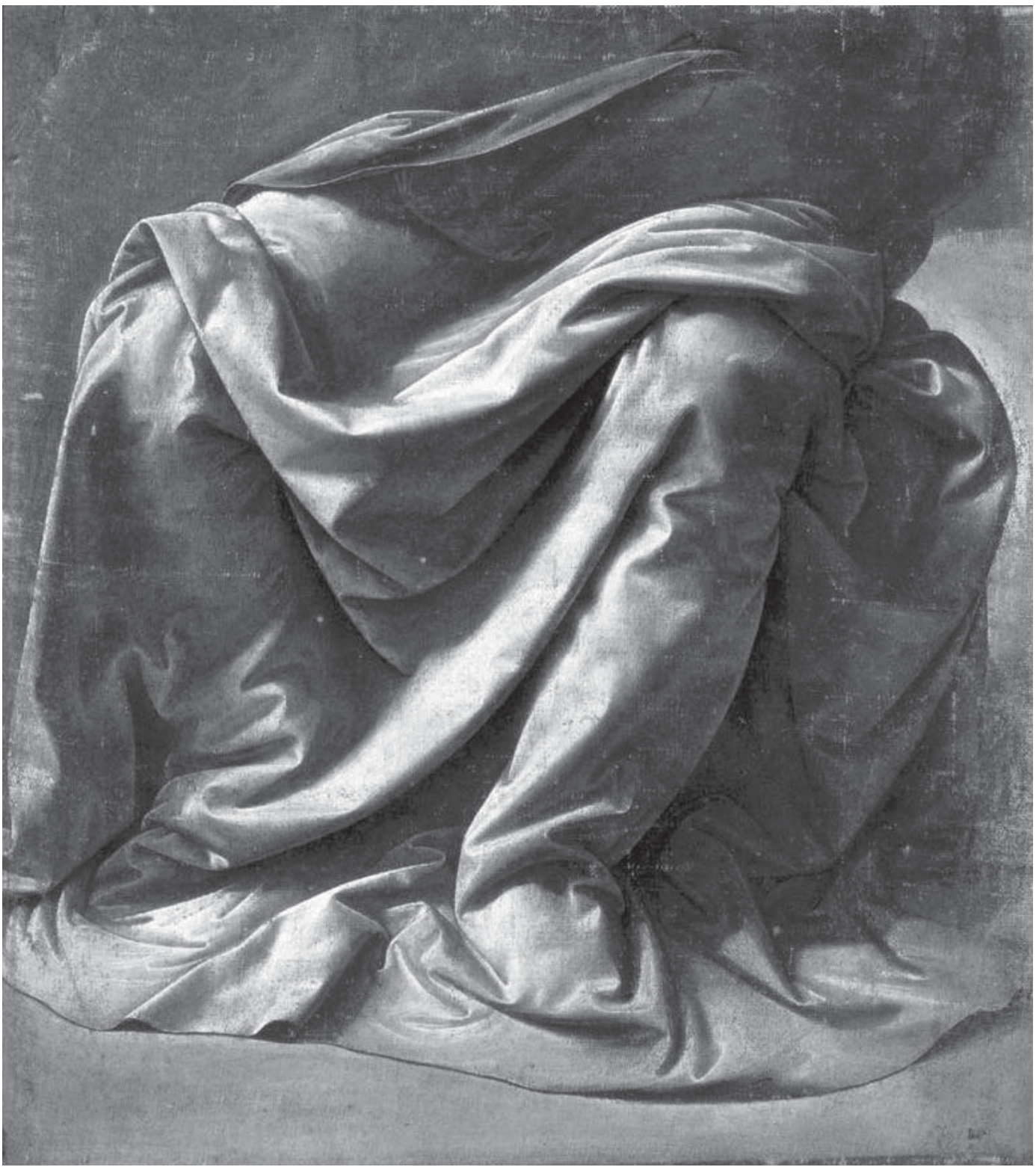

Ilustração 2. Leonardo da Vinci. Estudo de panejamento. Têmpera sobre linho preparado em cinza, 26,5 x 25,3 cm, circa 1480. Musée du Louvre, Paris. Fonte: Web Gallery of Art <www.wga.hu〉. O estudo aqui apresentado é o mais importante de um conjunto de dezesseis estudos. Vasari descreve sua realização no ateliê de Verrocchio e, embora não se possa dizer que o presente estudo foi usado em uma pintura, diversas pinturas feitas em torno do ateliê de Verrocchio mostram a utilidade de estudos como esse, como a Anunciação do próprio Leonardo, hoje na Galleria degli Uffizi. 


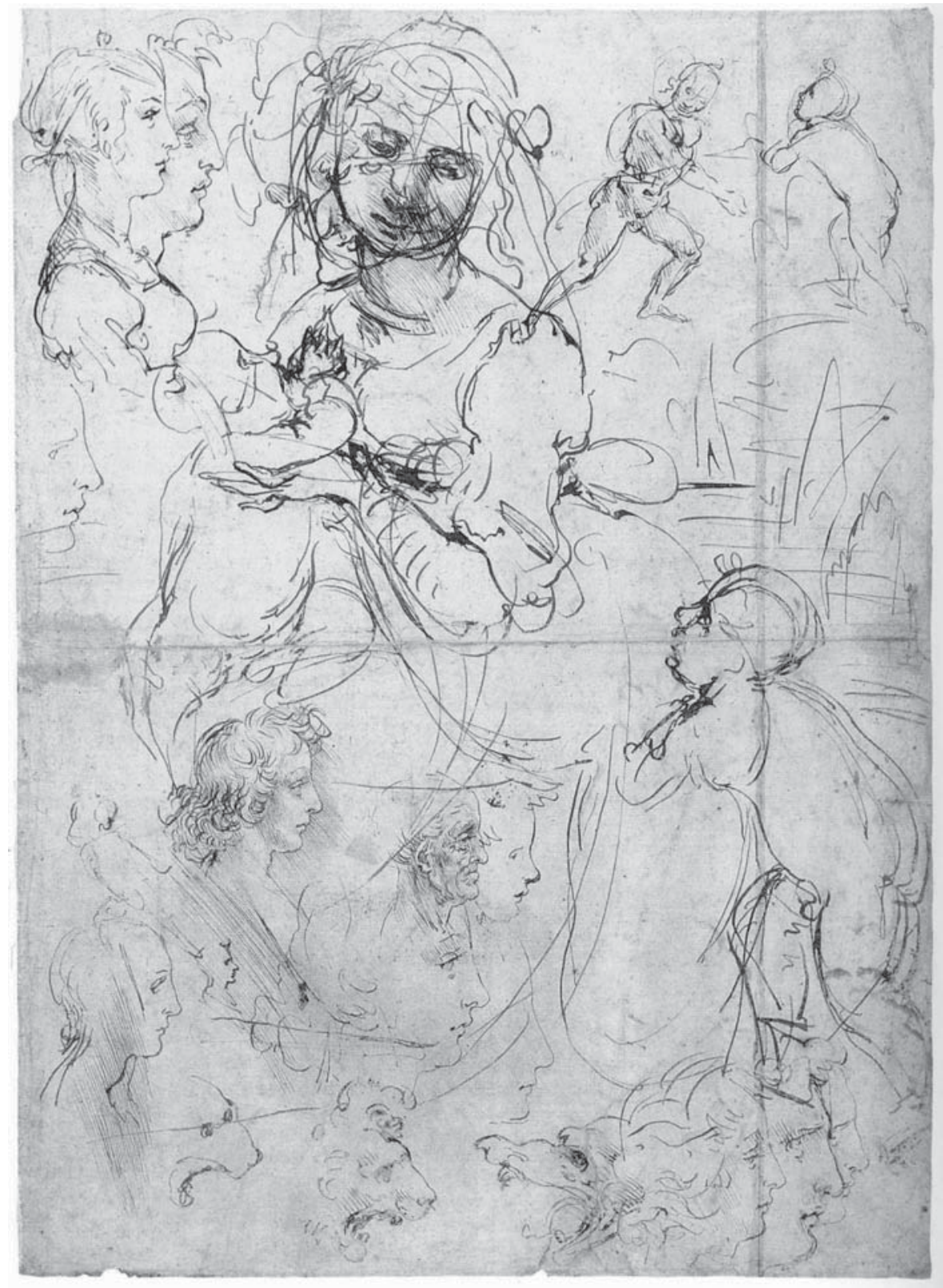

Ilustração 3. Leonardo da Vinci. Estudos diversos. Pena e nanquim sobre papel, 4, 0, 4, X 29,1 cm, circa 1478. Royal Library, Windsor. Fonte: Kemp, M. \& RoberTs, J. Leonardo da Vinci. Artist - scientist - inventor. London: Yale University Press/South Bank Centre, 1989. Este fólio é um dos primeiros que mostra a invenção do esboço. A figura principal, a Virgem com o menino, tem sua cabeça esboçada duas vezes, e sugere como Leonardo "modelava" suas figuras ao desenhar em vista a ter os "membros [das figuras] apropriados aos movimentos da mente". Ao longo dos anos, o estudo de tais movimentos levou Leonardo ao estudo da anatomia de modo inédito, ao menos para um artífice. 


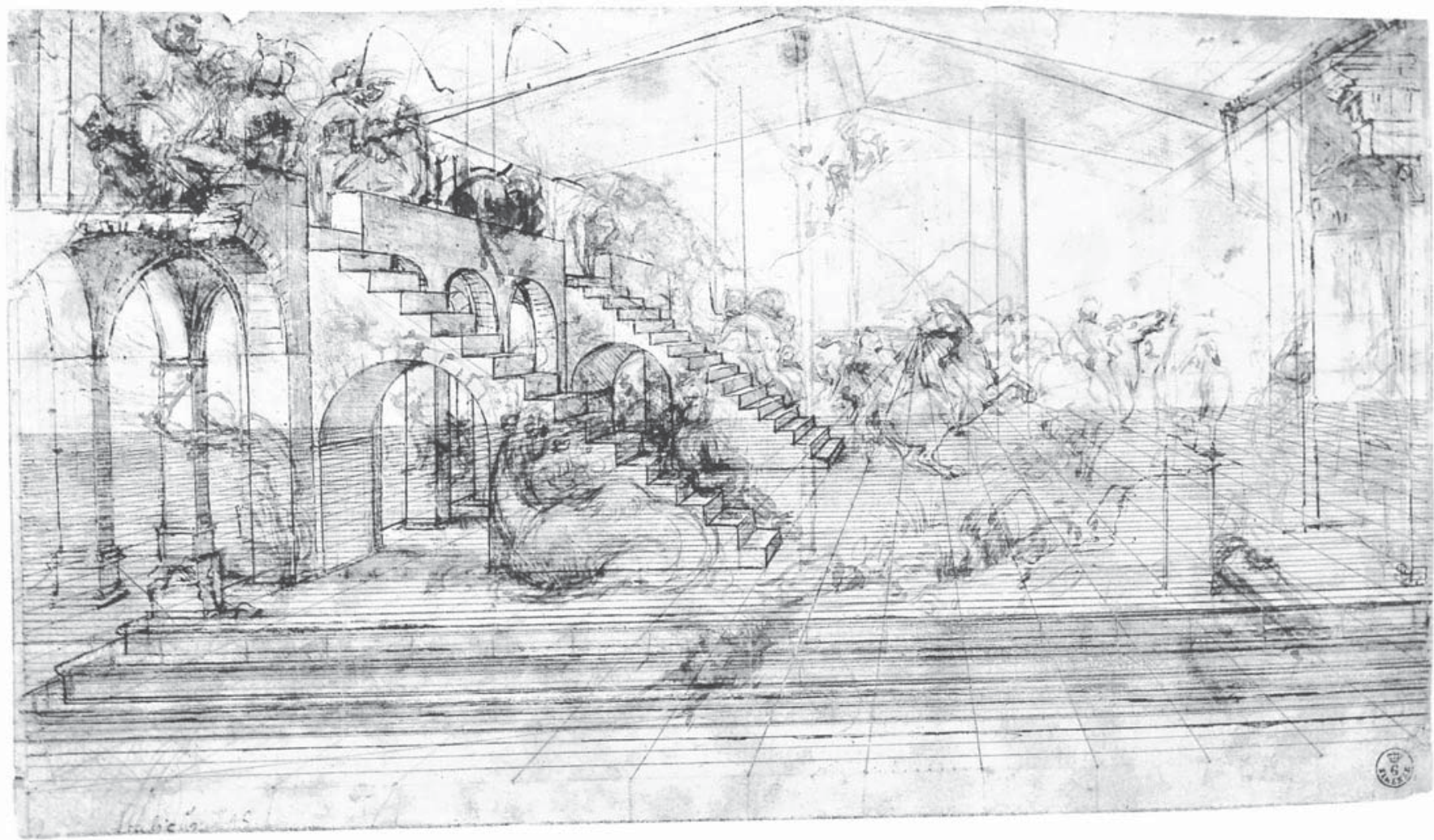

Ilustração 4. Leonardo da Vinci. Estudo de perspectiva para a Adoração dos Magos. Pena, nanquim e aguada sobre ponta de metal sobre papel, 16,2 x 29, $\circ \mathrm{cm}$, circa 14,81. Galleria degli Uffizi, Florença. Fonte: Library of the Congress <www.loc.gov/today/pr/2006/06-220.html〉. Este estudo de perspectiva, que não corresponde ao painel inacabado hoje na Galleria degli Uffizi, aponta para mais um aspecto da formação dos artífices florentinos no final do século xv, isto é, o aprendizado da perspectiva geométrica. Além disso, esse estudo mostra também o brainstorm de Leonardo ao compor uma história. 
A gitência Visual de Leonardo da Vinci...

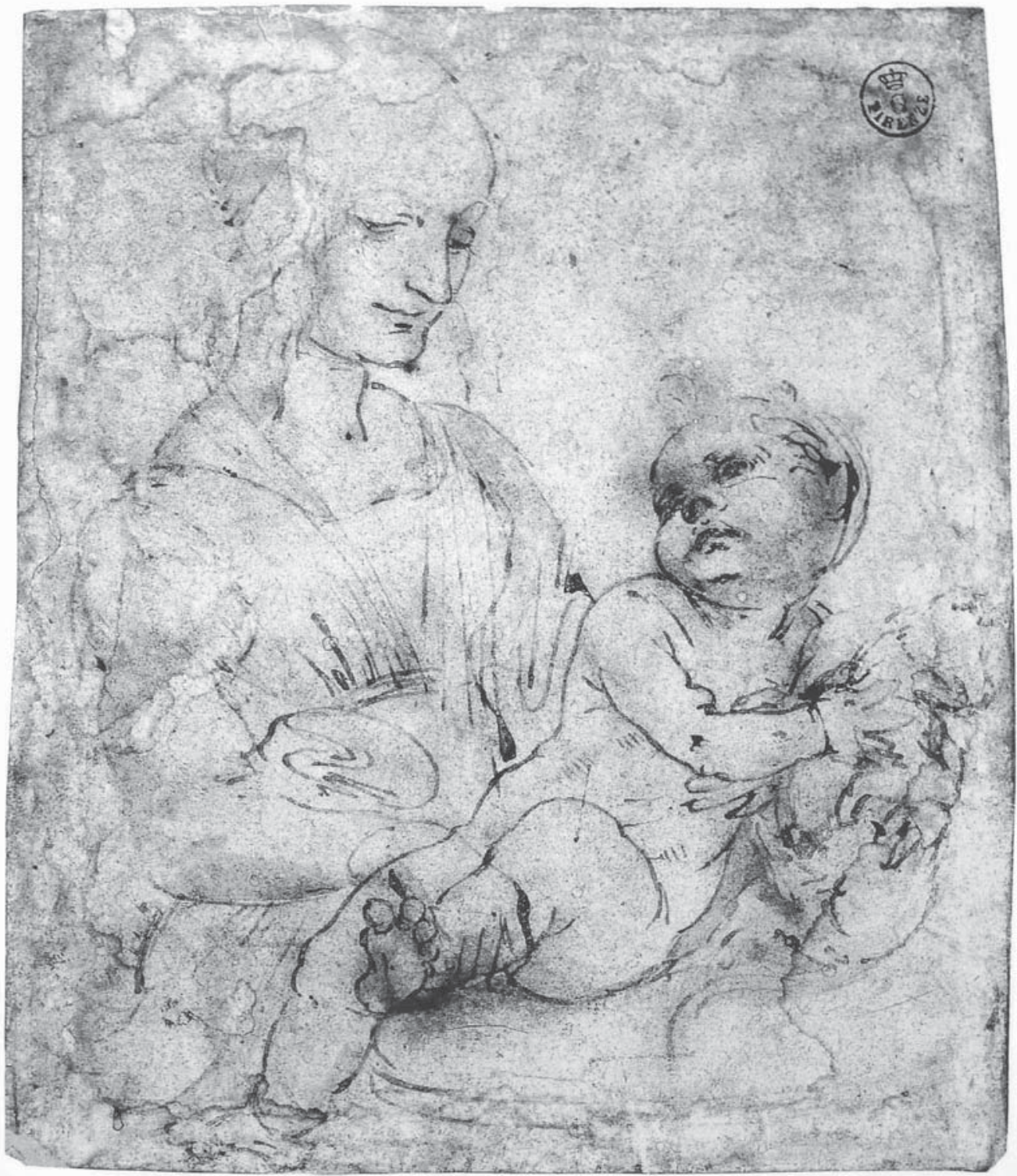

Ilustração 5. Leonardo da Vinci. Estudo para Madona com o menino e gato. Pena, nanquim e aguada sobre papel, 13,2 x 9,5 cm, circa 1478. Galleria degli Uffizi, Florença. Fonte: Zöllner, F. Leonardo da Vinci, 14521519. The complete paintings and drawings. Köln: Taschen, 2003. Este pequeno estudo, do qual não se conhece uma pintura resultante, mostra mais uma vez, nas palavras de Vasari, como Leonardo "deu a suas figuras o movimento e o sopro de vida". A falta de um esquema perspectivo não impede que se veja um espaço, dado o escorço da figura do menino nos braços da Virgem. 


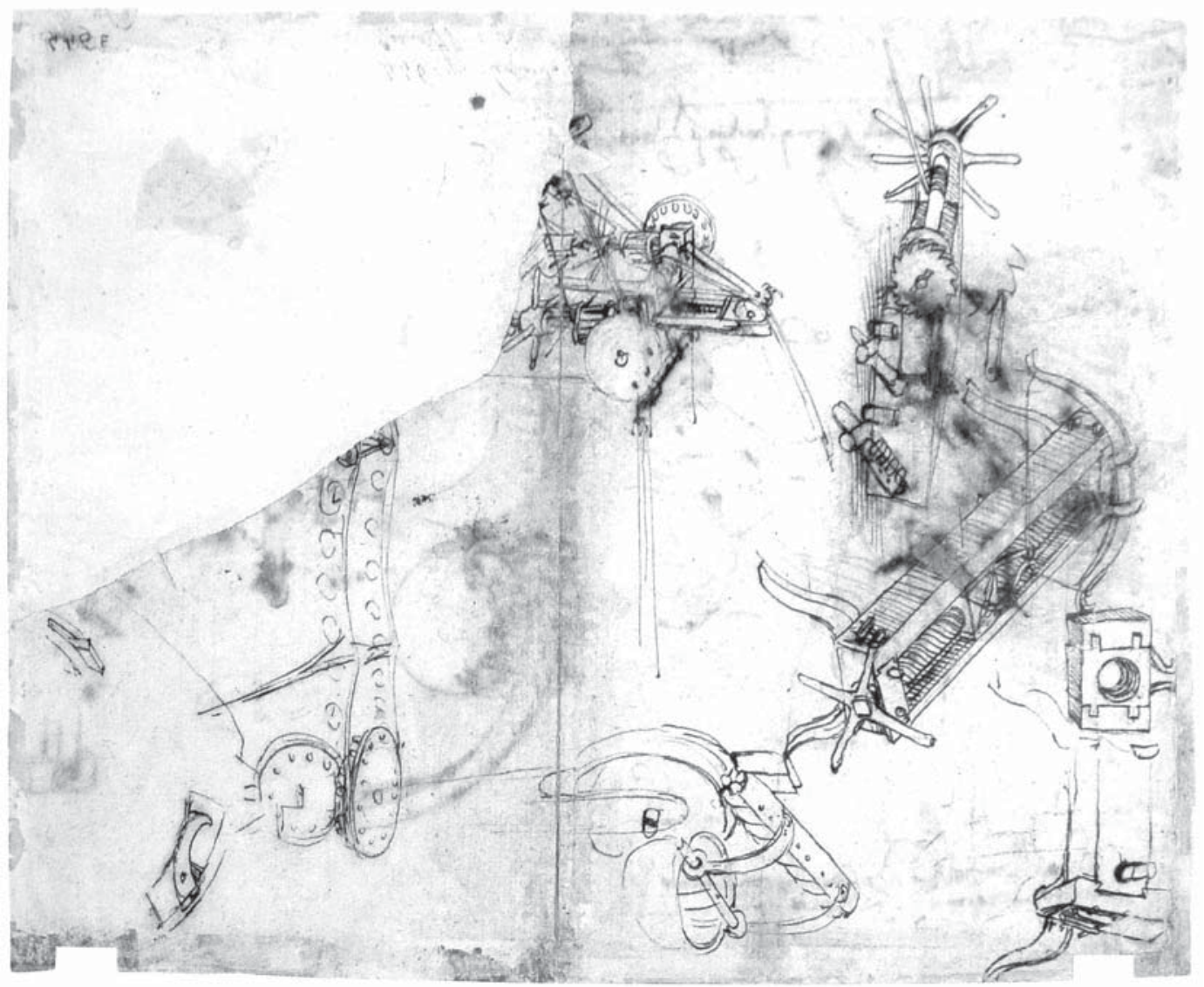

Ilustração 6. Leonardo da Vinci. Estudos de máquinas diversas. Pena e nanquim sobre papel, 20,2 x 26,6 cm, circa 1478. Galleria degli Uffizi, Florença. Fonte: Web Gallery of Art. Disponível em: 〈www.wga.hu〉. Este fólio apresenta um dos primeiros estudos de máquinas de Leonardo hoje existentes. Seu tratamento perspectivo ainda é deficiente e recorda os estudos contemporâneos do sienês Francesco di Giorgio Martini. A falta de organização do fólio e dos textos aponta para a formação de Leonardo em seu período florentino. 
A giência visual de Leonardo da Vinci...

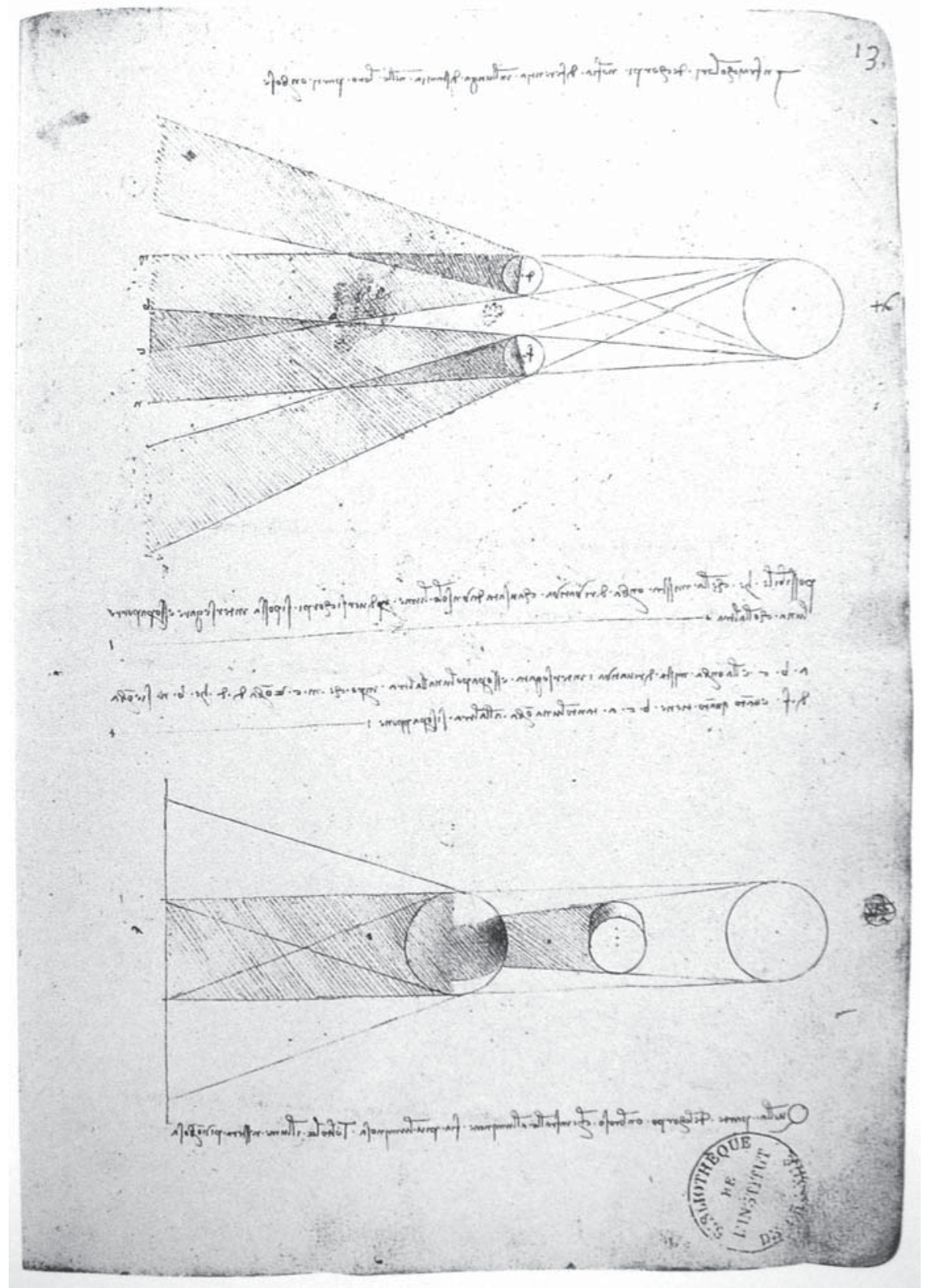

Ilustração ๆ. Leonardo da Vinci. Ms. C (fol. 2 recto). Pena e nanquim sobre papel, 32,8 8 23, o cm, 1490-93. Bibliothèque de l'Institut de France, Paris. Fonte: Biblioteca Leonardiana de Vinci. 0 Manuscrito $C$ contém notas a respeito de matérias diversas, mas seu argumento central é o comportamento de luzes e sombras sobre os corpos geométricos. A distribuição dos desenhos e textos sobre diversos fólios, a precisão dos desenhos e da caligrafia, assim como a prosa latina (com os verbos ao final das frases etc.), como na página mostrada acima, sugerem que o Manuscrito $C$ é, em grande parte, uma compilação de material previamente elaborado. Este fólio mostra Leonardo buscando dar regras a suas percepções. 


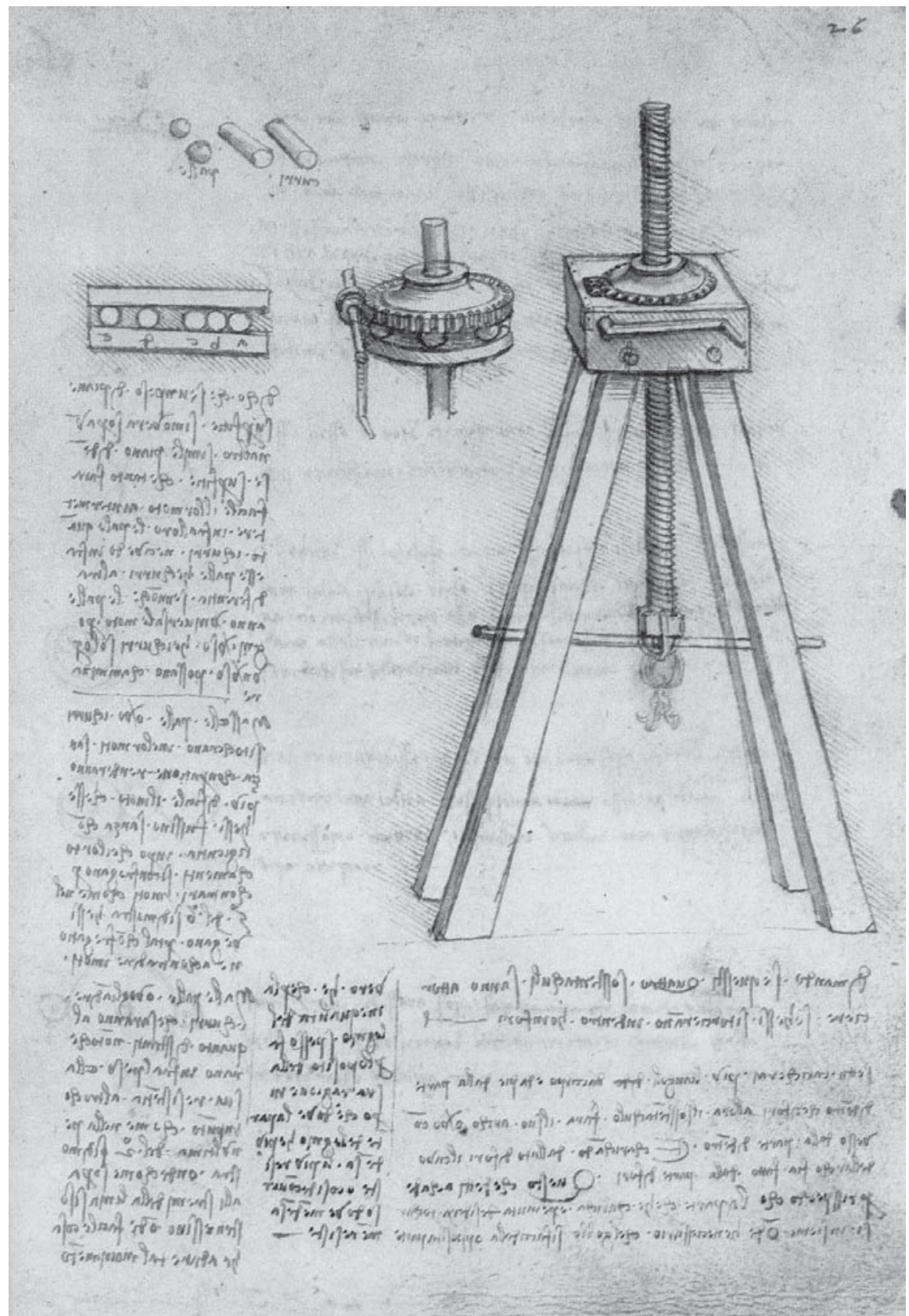

Ilustração 8. Leonardo da Vinci. Códice Madrid I (fol. 26 recto). Pena e nanquim sobre papel, 21 x 15 cm, 1490-99. Biblioteca Nacional, Madrid. Fonte: Biblioteca Leonardiana de Vinci. Este é um dos fólios do Codice Madrid I que exemplifica a "anatomia das máquinas” de Leonardo da Vinci. A figura principal mostra uma espécie de guindaste com sua "armadura", e a figura à esquerda mostra-o "anatomizado". A diferença entre esse fólio e o fólio florentino mostra até que ponto Leonardo conseguiu sofisticar sua formação em poucos anos. 
Esse era, em poucas imagens e palavras, o arsenal que Leonardo tinha para aproximarse da anatomia, de que se fala a seguir.

Leonardo da Vinci possivelmente começou seus estudos de anatomia ainda em Florença. Esses estudos estavam direcionados à realização de pinturas e obras semelhantes, tal qual faziam os artífices contemporâneos como Pollaiolo. Uma pintura como São Jerônimo, datada de aproximadamente 14,80, exigiu de Leonardo o conhecimento de estruturas do corpo visíveis externamente e, talvez, alguma observação de dissecações (ver fig. 8). Por volta de 1481-1482, Leonardo transferiu-se para Milão e, pouco após, em vista da valorização de suas artes e de sua posição social como artífice, ele começou a cuidar de sua formação, lendo e redigindo manuscritos, que contêm listas de vocábulos, desenhos de máquinas acompanhados de textos e estudos de filosofia natural, especialmente óptica, anatomia e física dos pesos (isto é, a estática), além de estudos de geometria e matemática. A polêmica com os poetas citada acima fazia parte desse contexto.

Por volta de 1485 , Leonardo iniciou seus estudos de anatomia relacionados à anatomia ensinada nas universidades. $\mathrm{O}$ fólio que contém um desenho esquemático da coluna e da medula de uma rã aponta para um experimento que Leonardo fizera (fólio 1). Outro fólio mostra os ventrículos cerebrais descritos por textos da tradição (fólio 2). Aqui se começa a ver como Leonardo elaborava concepções usando o desenho. No desenho, na parte inferior à esquerda, ao contrário da tradição em que o primeiro ventrículo recebia todas as impressões dos sentidos, aqui o primeiro ventrículo recebe apenas as impressões visuais e o segundo ventrículo recebe as impressões auditi-

Figura 8. Leonardo da Vinci. São Jerônimo penitente. Óleo sobre madeira, $103 \times 75 \mathrm{~cm}$, circa 148 o. Pinacoteca Vaticana, Roma. Fonte: Web Gallery of Art. Disponível em: 〈www.wga.hu〉. Ao contrário das práticas usuais dos ateliês da época, segundo as quais cada pintura era preparada meticulosamente através de desenhos, este painel inacabado sugere que Leonardo elaborava suas composições sobre os próprios painéis a pintar. Curiosamente, o pescoço do santo lembra diversos estudos de anatomia que Leonardo fez trinta anos após (ver fólio 25).

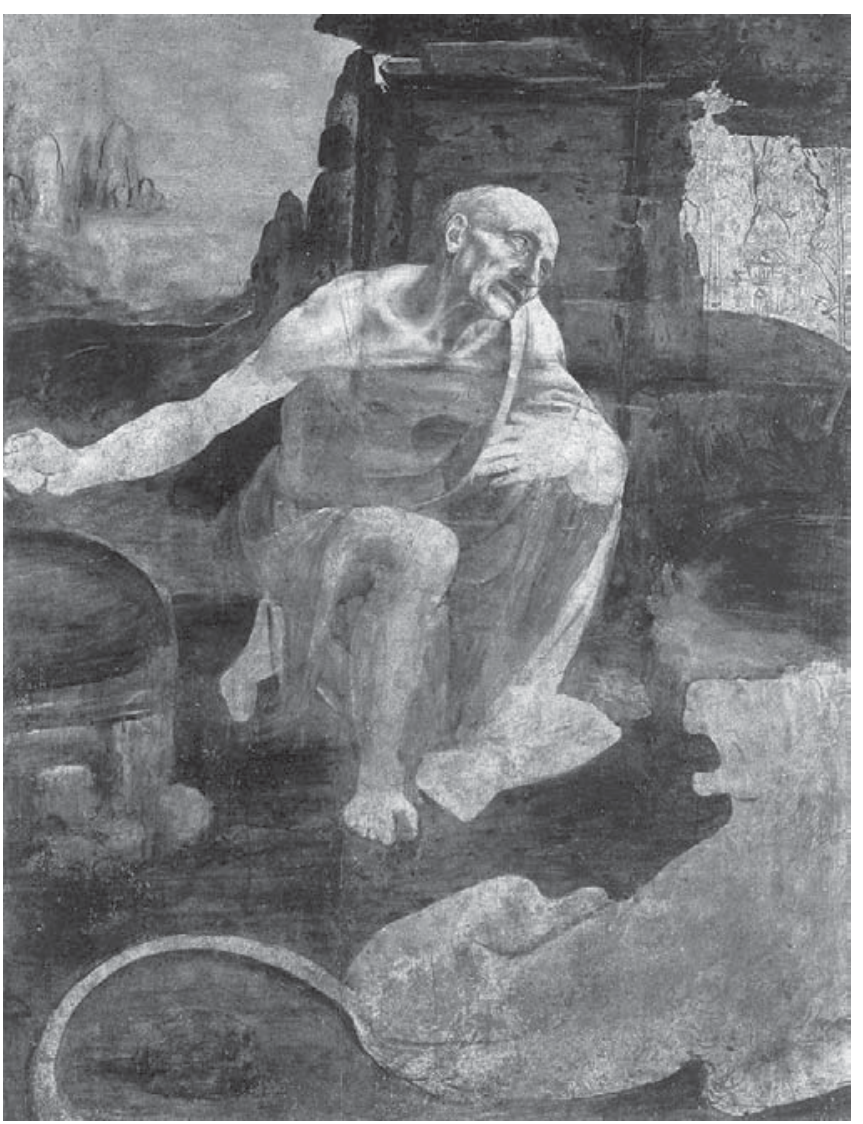


vas e olfativas, sugerindo, assim, a primazia das sensações visuais sobre as outras, a qual Leonardo precisava para justificar o elevado estatuto de conhecimento da pintura que ele então já defendia, conforme mostram os textos iniciais do Livro de pintura (cf. Leonardo da Vinci, 1995). Esse desenho e o desenho dos órgãos internos apontam para a formação de Leonardo e suas primeiras dissecações anatômicas, possivelmente de partes do corpo humano, assim como para o fato de que ele dava formas sensíveis a matérias da tradição textual, explorando-as não com palavras, mas com desenhos. $\mathrm{O}$ verso desse fólio mostra Leonardo explorando tanto as matérias anatômicas, neste caso, os músculos da extremidade inferior, quanto os modos de demonstrá-las, neste caso, demonstrações em cortes e com letras, embora aqui não esclarecidas por textos (fólio 3). Nesse contexto, a distância entre Leonardo e os artífices começava a aparecer, em virtude de seus interesses por matérias diversas dos interesses deles. Paralelamente, Leonardo distanciava-se dos anatomistas de sua época, dada sua ideia de conhecer a anatomia do homem por meio do desenho. Se, em Florença, ele aplicara os conhecimentos de anatomia em suas pinturas, agora ele começava a aplicar seu desenho aos estudos de anatomia. Aqui principiava a "ciência visual" de Leonardo da Vinci.

Após esses estudos iniciais, Leonardo começou a ordenar a anatomia do homem em escala ampla. O texto "Da ordem do livro" visa a descrição de diversos aspectos da figura humana, tais como a concepção, as medidas e a anatomia descritiva, os movimentos, as atitudes e os sentidos (fólio 4). Esse texto não consiste na descrição de investigações feitas, mas propõe as matérias a investigar e os modos de mostrá-las e ordená-las. O texto é original em relação à tradição, no sentido de que mostra uma disposição das matérias anatômicas diferente daquela utilizada nos tratados da época. As menções a respeito de desenhar e de figurar são claras e, ao final, elas estão relacionadas às partes do corpo responsáveis por expressões específicas. Não obstante o tratamento de tópicos especializados, a pintura permanecia como pano de fundo, no sentido de que Leonardo buscava conhecer a anatomia tendo em vista a representação dos movimentos corporais que, por sua vez, expressavam os "movimentos do ânimo" das figuras. Entretanto, Leonardo sabia da importância das palavras, como mostram as expressões "escrevas sobre atitudes e movimento" presentes nesse texto. O fólio a seguir também mostra Leonardo buscando entender e "figurar as causas" dos movimentos do corpo (fólio 5 ). A busca das causas ocorre nos moldes da filosofia natural aristotélica, no sentido de que se tem conhecimento demonstrativo de algo quando se conhece suas causas ou princípios.

Os fólios sobre o crânio humano mostram Leonardo em um nível de organização inédito até então. $O$ primeiro desses fólios (fólio 6) revela que Leonardo cortou um crânio para mostrar partes específicas, tendo uma apresentação que remete a uma pá- 
gina impressa. De fato, esse é um raro desenho dal naturale do corpus de estudos anatômicos, dado que Leonardo, de modo geral, compunha de memória suas demonstrações sem ver diretamente as dissecações, como mostram os primeiros fólios mencionados acima. De fato, o outro fólio mostra um desenho composto por duas vistas, tal como apontado por Clayton (cf. 1992, p. 37), e mostra como Leonardo compunha suas demonstrações, inclusive quanto tinha material anatômico a sua disposição (fólio ఛ).

O fólio com as camadas da cabeça e os ventrículos cerebrais sugere as dificuldades de Leonardo relativas ao acessar a corpos para dissecação e suas leituras de textos da tradição. Esse fólio é menos organizado do que os fólios do crânio humano, embora mostre Leonardo elaborando novos modos de apresentar as matérias anatômicas (fólio 8). A vista em corte da cabeça não está adequada a suas partes superficiais, mas os pequenos desenhos na parte de baixo do fólio sugerem novamente modos de mostrar a anatomia por meio de cortes, modos possivelmente derivados do tratado Da perspectiva de pintar de Piero della Francesca (cf. Panofsky, 1962, p. 153-5). É importante ressaltar também que, se, por um lado, Leonardo seguia a tradição medieval a respeito dos ventrículos cerebrais, por outro, o fólio em questão apresenta a primeira representação conhecida do seio frontal.

O estudo do fólio da cópula (fólio 9) é um esboço em que aparece de modo evidente o novo modo de desenhar de Leonardo, agora no âmbito da filosofia natural. Esse esboço mostra que, se ele não tinha acesso a cadáveres, ele lia os textos de anatomia e buscava dar forma a suas ideias com o desenho. O fólio resultante (fólio 10) ainda tem muito de esboço e de partes não observadas, como o canal que sai da medula e vai ao pênis, conforme a tradição de Hipócrates, e Leonardo explorou outros modos de mostrar partes do corpo, no caso em corte sagital da figura principal e as duas vistas do pênis. A menção a Avicena aponta para a formação e os interesses de Leonardo nessa época. Nesse contexto, ele começava a pensar a respeito de sua ciência visual, como sugere um memorando contemporâneo aos fólios citados:

Entenderás bem estes [intestinos], com seu dobrar-se, se tu os inflares. E recordes que depois que tu os tiveres feito por quatro lados assim ordenados, faça-os estendidos por outros quatro aspectos, de modo que, por seus espaços e perfurações, tu possas entender o todo, isto é, a variedade de seus volumes (K/P, 39 verso).

Após isso, Leonardo passou diversos anos sem estudar anatomia, mas continuou a desenvolver seus modos de desenhar em diversas direções. Por volta de 1490-93, Leonardo escreveu e compilou o chamado Manuscrito $C$, que trata do comportamento de luzes e sombras sobre os corpos geométricos (ver ilust. ₹). Vê-se como Leonardo 
buscava colocar ciência em sua arte de desenhar. De fato, vê-se semelhanças entre o desenho inferior desse fólio e o primeiro estudo do crânio humano mencionado acima. Ao lado disso, ele também estudava a mecânica de sua época, em especial a física dos pesos. Por volta de $1495^{-14}$, 99 , Leonardo compôs e organizou o manuscrito hoje conhecido como Codice Madrid I, no qual se vê a primeira sistematização da arte de construir máquinas que utilizava elementos da geometria e da física de sua época (cf. Galluzzi, 1987, 1995). Tendo esses conhecimentos, Leonardo concebia máquinas diversas, inclusive "anatomizando-as", como mostram diversos fólios do Codice Madrid I (ver ilust. 8). Leonardo escreveu a respeito disso no Codice Madrid I:

E tais instrumentos serão figurados sem suas armaduras ou outras coisas que impediriam o olho daquele que os estuda. Depois, essas mesmas armaduras serão descritas por meio de linhas e, após isso, as alavancas e a força dos suportes (Leonardo da Vinci, 1974, fólio 82 recto).

As ilustrações desse fólio mostram o progresso de Leonardo em relação ao fólio da época florentina (ver ilust. 6), seja quanto às matérias, seja quanto aos modos de mostrá-las, um progresso comparável às diferenças entre as duas pinturas que abrem este texto (ver fig. 1 e 2).

Leonardo retomou seus estudos de anatomia por volta de 1505 . O fólio com estudos diversos (fólio 11) apresenta um esboço do abdome seguido de um texto que contém uma rara menção ao ato de desenhar durante uma dissecação. Esse fólio mostra que desenhar era um dos instrumentos que Leonardo tinha para guiar suas investigações. Os textos já direcionavam as observações de Leonardo, sendo que ele repetiu diversas concepções da tradição textual, e os textos que ele próprio escrevia também direcionavam suas experiências, pois apontavam para as formas a buscar e a observar. Desenhar era outro modo de Leonardo ordenar suas experiências de dissecação. Ao esboçar e precisar a forma de um órgão e ao ver seus desenhos, como no fólio em questão, Leonardo preparava-se para suas experiências a seguir.

O fólio dos ventrículos cerebrais apresenta uma investigação inédita de Leonardo (fólio 12). Formado no ateliê de um escultor, Leonardo injetou cera líquida no cérebro de um boi para descobrir suas formas. Leonardo sugere que o objetivo principal era ver "perfeitamente" as formas dos ventrículos, e o uso de transparências mostra mais uma vez como Leonardo buscava modos novos de apresentar seus resultados. Pode-se supor que as formas de cera que Leonardo obteve de sua investigação não tinham uma aparência regular e, assim, ele elaborou um desenho ideal dessas formas. De fato, vê-se que Leonardo esboçou o desenho principal com carvão e, em um segundo momento, cobriu seu esboço com nanquim, em uma forma de desenhar que se apro- 
xima de seus esboços preparatórios para uma pintura. Vê-se também a convivência entre o velho e o novo, no sentido de que Leonardo, ao lado de sua investigação inédita e de sua forma nova de mostrar a anatomia do corpo humano, aceitava as concepções tradicionais dos ventrículos como sede do pensamento. A figura em corte sagital enfatiza o novo modo de mostrar a anatomia (fólio 13), e o texto do fólio com estudos dos músculos das costas é revelador de como Leonardo buscava compor o corpo humano em suas demonstrações (fólio 14), tal qual Alberti sugerira em seu próprio contexto, como citado acima: "primeiro, o pintor colocará cada osso do animal em sua posição, e após seus músculos e então suas carnes" (Alberti 1973, cap. 36). Tal qual o desenho em corte, esse tipo de demonstração "de dentro para fora" não era feita dal naturale, mas sim a partir de conhecimentos de anatomia e do desenho já sistematizados pela óptica. Esse fólio também menciona saber as "razões" (no sentido de causas ou explicações) e os "ofícios" (no sentido de funções) de cada músculo. Assim, Leonardo compunha o corpo humano informado por suas causas.

Pouco após, Leonardo intensificou suas atividades como anatomista. O marco é a dissecação de um homem centenário, que Leonardo realizou em Florença no inverno de ${ }_{15} 07$ para 1508 (fólio ${ }_{15}$ ). A dissecação do centenário resultou em diversas descobertas, como, por exemplo, a primeira descrição da condição patológica que hoje se chama arteriosclerose. Os fólios do período são fólios feitos distante das dissecações e apresentam desenhos idealizados, como na simetria exagerada dos vasos (fólio 16) e no viés mecânico de suas formas, elementos que vinham de seus estudos de máquinas (fólio 17). ${ }^{\mathbf{1 3}}$ A transparência e a vista explodida da cabeça mostram o engenho e a arte de Leonardo ao compor uma demonstração, e o fólio baseado sobre a anatomia do porco aponta para a realização de um tratado de anatomia de grandes proporções (fólio 18 e 19). O aspecto irreal de muitas estruturas também fica claro na grande demonstração dos órgãos femininos (fólio 20), na qual também aparece a simetria exagerada dos vasos e um útero derivado das descrições de Mondino, autor citado e criticado no fólio. Essa grande síntese é próxima de um texto que aponta diretamente para as disciplinas que um anatomista tinha de saber:

E se tu tiveres amor por tais coisas, talvez sejas impedido pelo estômago, e se este não te impedir, tu serás talvez impedido pelo pavor de estar durante a noite em companhia de tais mortos cortados e esfolados, horríveis de ver-se. E se isto não te impedir, talvez faltará em ti o bom desenho, o qual pertence a tal representação, e se tu tiveres o desenho, este não será acompanhado com a perspectiva, e se

13 Galluzzi $(1987,1995)$ apresenta a história dos desenhos de máquinas até Leonardo e, como se faz neste artigo, mostra como Leonardo utilizou suas "anatomia das máquinas” ao estudar a anatomia do homem de 1508 em diante. 
esse assim for, faltará em ti a ordem das demonstrações geométricas e a ordem dos cálculos das forças e virtudes dos músculos. E talvez faltará em ti a paciência, de modo que tu não serás diligente (K/P, 113 recto).

Fica claro que o engenho e a arte de desenhar eram regrados pela perspectiva, e para a anatomia era também necessário saber geometria e matemática. De fato, dois memorandos desse fólio de estudos apontam diretamente para isso. $\mathrm{O}$ primeiro diz: "faças traduzir o livro Das utilidades de Avicena." Leonardo faz referência a um livro a respeito dos ofícios das partes do corpo. O segundo, por sua vez, associa os ofícios aos estudos da física dos pesos: "o livro da ciência das máquinas vai antes do livro das utilidades." Tendo aprofundado as ciências em questão, Leonardo pôde fazer estudos mais elaborados por volta de 1510 , talvez em colaboração com o anatomista Marcantonio della Torre, ${ }^{\mathbf{1 4}}$ os quais são aqui introduzidos por um texto que enfatiza o uso dos desenhos e da prática anatômica para chegar a eles (fólio 21). Os textos principais desse fólio são ampliações de uma frase do plano de 1489. ${ }^{15} \mathrm{O}$ contexto desse plano, que inclui a pintura, sugere o leitor anatomista a que Leonardo se dirigia, talvez apenas aqueles que dividiam com ele suas concepções a respeito da anatomia e da pintura talvez apenas ele próprio. O último texto expõe em detalhes as etapas da demonstração da mão.

Os fólios a seguir (22, 23 e 24) exploram isso de diversos modos, como nos fólios das demonstrações da mão, do braço e da coluna. Nos dois últimos fólios, praticamente prontos para publicação, Leonardo enfatiza o uso dos desenhos. O fólio da coluna vertebral mostra a coluna em três aspectos e a coluna cervical em uma vista explodida, mostrando o engenho e a arte de Leonardo ao apresentar a anatomia do homem, em parte derivada de seus estudos de máquinas feitos anos antes. Os textos descrevem e/ ou explicam as partes desenhadas, e pode-se ver aqui o quão Leonardo organizara seu conhecimento da anatomia do homem. O estado da ciência de Leonardo pode ser observada também no texto para justificar seu novo modo de apresentá-la, assim como na menção à publicação de seus estudos. ${ }^{16}$

Nessa época, Leonardo inventou diversos outros modos de demonstração anatômica, como as demonstrações dos músculos como fios, como modo de mostrar a causa de cada movimento (fólio 25). No fólio que apresenta um grande desenho da ex-

14. A fonte para essa suposição é Vasari (cf. 1822, III, p. 24-25). Diversos fólios desse período apontam para concepções de Galeno, que segundo Vasari começava a ser introduzido justamente por Marcantonio.

15 Cf. fol. 4: "Depois, descrevas como ele é composto de vasos, nervos, músculos e ossos."

16 A palavra que falta na última nota do fol. 24, é possivelmente "legno", isto é, Leonardo pede para que seus desenhos não fossem impressos usando xilogravuras. A respeito disso, cf. Reti (1971). 
tremidade inferior, evidentemente uma síntese de diversos outros desenhos, lê-se outro texto a respeito do uso de fios, além de mais uma crítica a Mondino e outra menção a Avicena (fólio 26). Esse modo de demonstrar está explicado no último texto do fólio seguinte, que também faz explícita a ideia de Leonardo para "figurar a causa dos movimentos de qualquer membro" (fólio 27). Outro fólio mostra desenhos que seguem essa preceptiva, agora combinados com vistas explodidas da anatomia profunda do ombro, formas que ele tinha de compor de memória após realizar dissecações (fólio 28). Em outro fólio, Leonardo menciona uma regra para desenhar "sem ver o [modelo] vivo" e mostrar "quase todos os atos sem erro", voltando, assim, à ideia de "figurar as causas" (fólio 29). O texto sugere relações entre a anatomia e a pintura, dado o fólio em que está e a menção aos atos de um modelo, ou seja, a anatomia servia para a descrição dos movimentos da figura e a expressão de seus movimentos do ânimo. Os esquemas geométricos presentes nesses fólios mostram tentativas de Leonardo de calcular as "forças e virtudes dos músculos", algo inédito nos textos de anatomia da tradição. ${ }^{17}$

O último período das investigações anatômicas de Leonardo é marcado pela originalidade de suas matérias, mas um tanto decepcionante em termos de seus modos de demonstrar. Os estudos tratam do coração e dos movimentos do sangue em seu interior, e parecem pertencer a cadernos de esboços, nos quais não se observa uma organização como no período anterior. Não obstante, Leonardo revela seu grande engenho ao ilustrar o coração em sístole e diástole (fólio 3o) e as válvulas do coração em esquemas geométricos (fólio 31). Esse fólio e o fólio que apresenta as câmaras do coração (fólio 32) mostram Leonardo buscando as formas do coração com o desenho. Na série de que esses fólios fazem parte, o fólio que apresenta o coração e os brônquios (fólio 33) contém um texto que mais uma vez justifica os modos de Leonardo e sua relação com a pintura.

Por fim, os fólios do feto humano mostram o engenho e a arte de Leonardo como anatomista e demonstrador. Os dois desenhos centrais do primeiro fólio (fólio 34) mostram Leonardo mais uma vez esboçando suas demonstrações com sanguínea antes de cobri-las com nanquim, e o segundo fólio mostra uma demonstração composta por um feto humano e um útero bovino e um desenho extraordinário em que Leonardo mostra as membranas do útero.

17 Não existe a menor menção a isso no texto Anatomia de Hieronymo Manfredi, escrito por volta de 1490. Segundo Singer (1975, p 105), esse texto é uma ampliação do texto de Mondino que, mesmo sem exibir feições originais ou desvios significativos das fontes, representa a tradição de Mondino como estava em Bolonha no final do século xv, sendo assim o escrito mais satisfatório antes da publicação dos dois principais textos de Berengario da Carpi. Cf. o texto integral de Manfredi em Singer (1975). 


\section{A Giêngia nos estudos de anatomia de Leonardo da Vingi}

Os estudos de anatomia existentes mostram que as investigações de Leonardo foram diversas da prática usual das escolas de medicina. Ele próprio indica o número de corpos que pôde acessar em alguns fólios, como ao dizer que dissecara "mais do que dez corpos humanos", e a dissecação do centenário realizada em um ospedale sugere um contexto fora das universidades. Isso aponta para uma abordagem inédita à anatomia.

Os estudos de anatomia existentes também mostram que Leonardo tinha por principal instrumento o desenho e visava mostrar/demonstrar a anatomia do homem. Em uma época em que a ilustração anatômica era rude (ver fig. 6), quando existente, os desenhos de Leonardo expressam concepções anatômicas, no sentido de que mostram as formas e os ofícios do corpo humano. Os textos completam os desenhos, no sentido de que informam noções que não eram ilustráveis. Mais importante do que isso, os fólios mostram que o desenho era o instrumento principal de exploração e elaboração do conhecimento adquirido em leituras e em dissecações, como sugerem os inúmeros desenhos circundados por textos. Enquanto Gombrich e Kemp apontam para desenhos no âmbito de pinturas, como citado no início deste texto, Arasse menciona que Leonardo inventou simultaneamente os "desenhos preparatórios" e a "ilustração científica" (Arasse, 2006, p. 56). Sem definir os termos "arte" e "ciência", Arasse destaca o desenho do crânio, uma síntese de duas vistas diferentes e os estudos da "grande demonstração", do feto e do coito, cada qual com suas "ficções" não observáveis (cf. 2006, p. 56). Tais ficções decorriam do modo de Leonardo compor suas demonstrações de anatomia. Arasse analisa, então, as formas que aparecem quando Leonardo desenhava: "com efeito, existe nele uma relação intrínseca entre a atividade do olhar, o ato gráfico e a revelação de uma forma pouco visível ou invisível na realidade" (2006, p. 65-6). Curiosamente, Arasse não mostra nem cita os esboços que mostram Leonardo explorando diferentes formas de representação para as formas anatômicas, tal como mostrado acima. Pode-se, então, ir adiante.

Leonardo não tinha o objetivo de realizar um conhecimento de feição imitativa, no sentido de fazer desenhos de anatomia dal naturale para registrar suas dissecações. Usando um termo de seus manuscritos, "ritrare", ou seja, retratar dal naturale, não era um procedimento usual de Leonardo ao desenhar. Embora muitos desenhos tenham aparência naturalista, apenas poucos apresentam indícios de serem feitos dal naturale, como o primeiro estudo do crânio humano (fólio 6). De fato, não havia como desenhar dal naturale na maior parte dos casos. O material disponível e as condições pouco propícias para a realização de dissecações, como ele próprio sugere no texto em que fala dos "mortos cortados e esfolados, horríveis de se ver" (K/P, 113 recto), inviabilizavam isso, e as demonstrações "de dentro para fora", com sua ordem de exposição contrária 
à ordem de dissecação, não permitiam o desenho dal naturale. A ciência, de fato, não tratava de particulares, mas sim de noções universais apreendidas de diversos particulares, como Leonardo sabia ao escrever em um fólio com estudos do quiasma ótico: "Veja em outras anatomias se tal variação é universal a todos os homens e mulheres etc." (K/P, 55 recto). Leonardo desenhava suas demonstrações anatômicas a partir de seu conhecimento de textos e da memória de suas dissecações, idealizando formas e especulando a respeito de seus ofícios, inventando e compondo formas a partir de seus ofícios e, frequentemente, sintetizando muitas formas e ofícios em um único desenho. Assim, é possível pensar uma forma de imitação muito particular que visava elaborar uma nova interpretação do que era a filosofia natural.

Considerando o período tardio de suas investigações, no qual seus princípios aparecem definidos, Leonardo aproximava suas concepções de natureza e de conhecimento, como mostra o seguinte parágrafo do Manuscrito E, datado aproximadamente em 1508:

Mas primeiro farei alguma experiência antes que eu proceda, porque minha intenção é alegar primeiro a experiência e após com a razão demonstrar porque tal experiência é constrangida de tal modo a operar; e esta é a verdadeira regra pela qual os especuladores dos efeitos naturais têm de proceder. E ainda que a natureza comece da razão e termine na experiência, a nós é necessário seguir em contrário, isto é, começando (como eu disse acima) pela experiência, e com aquela [razão] investigar a razão [da natureza] (Leonardo da Vinci, 1989, fólio 55 recto).

Para Leonardo, existia uma razão na natureza ("ragione") que constrangia (cf. "constretta") os efeitos naturais ("effetti naturali"), e existia também a razão humana ("ragione" novamente) que investigava os efeitos naturais para conhecer a razão natural. A razão humana também regrava as atividades produtivas, no sentido de produzir a partir das causas. Assim, uma vez que a razão humana possuía o conhecimento da razão natural, ela podia reproduzir os efeitos naturais da natureza. Os textos que mencionam as disciplinas que o anatomista tinha de saber (cf. $\mathrm{K} / \mathrm{P}, 113$ recto), a necessidade de fazer diversas anatomias para conhecer aquilo que era ou não universal (cf. K/P, 55 recto, entre outros) e o "modo de figurar a causa dos movimentos de qualquer membro" (fólio 27), talvez, apontem as principais características da ciência anatômica de Leonardo da Vinci.

O procedimento de compor não era novidade. Como já foi citado no início deste texto, Cennini diz que convinha ao pintor "ter fantasia nas operações manuais, de encontrar coisas não vistas (fazendo-as sob a sombra do natural)" (Cennini, 1859, cap. 1). Alberti aponta para isso em diversas passagens do Da pintura, como por exem- 
plo na seguinte passagem: "Zeuxis, porque pensava não poder em um corpo apenas encontrar tanta beleza que buscava, elegeu cinco jovens entre as mais belas para extrair delas a beleza não encontrada em uma única mulher" (Alberti, 1973, cap. 56). Poucos anos após, Alberti aponta novamente para essa questão no Da estátua:

Declaro, de fato, que nosso método ou nosso engenho não permite expor minuciosamente como representar com semelhança absoluta ao real cada particular do rosto de Hércules em luta com Anteu, ou por quais traços esse diferencia-se do rosto do mesmo Hércules pacato e sorridente com Dejanira. Mas, porque todos os corpos, mudando-se as flexões e tensões dos membros e a posição das partes, têm formas diversas, necessita-se tratar daqueles procedimentos com os quais se pode imitar tais formas com um método racional seguro (Alberti, 1999, cap. 5).

Assim como a perspectiva dos artífices, que era um método de composição do espaço tridimensional em duas dimensões, também o cânone de proporções de Alberti visava regras gerais para compor figuras. A novidade de Leonardo estava em usar os esboços e, principalmente, passar isso para o âmbito da filosofia natural, tendo inclusive o desenho como instrumento para investigar e descobrir, como sugere o texto a respeito da bexiga (ver fólio 11). Em outras palavras, se o pintor e o escultor de Alberti tinham de ser doutos para serem eloquentes e verossímeis (no sentido da Poética de Aristóteles), o pintor de Leonardo tinha de ser douto para dizer a verdade (no sentido de demonstrações de matérias da filosofia natural).

O objetivo de Leonardo da Vinci era uma ciência cuja elaboração ocorria desenhando e cujos resultados expressavam concepções da filosofia natural da época. Disso, pode-se pensar que a ciência de Leonardo era uma disposição de produzir para demonstrar. Entretanto, se inserir conhecimentos de certas ciências em uma arte fazia suas operações seguras (ou mais seguras do que sem tais conhecimentos) e elevava seu estatuto, dada a possibilidade de dizer quanta ciência havia em uma operação e/ou na obra que de uma operação resultava, o contexto da época não permitia a síntese que Leonardo propunha. Assim como foi dito no início deste texto, segundo as categorias da época a arte era uma "disposição de produzir" no mundo da geração e corrupção, enquanto a ciência era uma "disposição demonstrativa" de causas e princípios eternos e necessários. A imitação ocorria sobre a matéria e resultava em desenhos, isto é, em formas sensíveis, mas não em conceitos abstraídos da experiência, isto é, discursos. Assim, uma forma de conhecer baseada na filosofia natural que tinha de ser realizada conjuntamente com uma arte não tinha lugar, ou seja, uma ciência que produzia aparências (mesmo que aparências idealizadas) era uma contradição nos seus próprios termos. 
Leonardo da Vinci lia pouco o latim e não escrevia como um homem letrado de seu tempo, mas sabia observar e desenhar como poucos. Ele tinha os instrumentos diversos dos anatomistas de sua época e, efetivamente, concebeu sua ciência anatômica de modo diverso da ciência dos anatomistas. Ele também tinha interesses diversos dos artífices de sua época, dadas as relações entre sua anatomia e sua pintura. O caso resta único, como sabia o humanista Paolo Giovio, ao escrever por volta de 1524 que Leonardo da Vinci "não deixou um único discípulo célebre" (Giovio apud Barocchi, 1971, p. 9).@

\section{Eduardo Henrique Peiruque Kigkhöfel}

Professor Doutor do Departamento de Filosofia,

Escola de Filosofia, Letras e Ciências Humanas, Universidade Federal de São Paulo, Brasil. kickhofel@hotmail.com

\section{REFERÊNGIAS BIBLIOGRÁFIGAS}

Alberti, L. B. Della pittura. In: Grayson, C. (Ed.). Opere volgari di Leon Batista Alberti. Bari: Laterza, $197^{3}$. v. 3, p. $5^{-107}$. De statua. Introdução e notas M. Collareta. Livorno: Sillabe, 1999.

Arasse, D. Arte e ciência: funções do desenho em Leonardo da Vinci. In: Fabris, A. \& Kern, M. L. B. (Org.). Imagem e conhecimento. São Paulo: Edusp, 2006. p. 55-73.

Aristóteles. Nicomachean ethics. Tradução H. Rackham. Cambridge: Harvard University Press, 1934. . Metaphysics. Tradução, introdução e notas W. D. Ross. Oxford: Oxford University Press, 1975.

Barocchi, P. (Ed.). Scritti d'arte del Cinquecento. Milano/Napoli: Riccardo Ricciardi, 1971. v. 1.

Bianchi, L. Continuity and change in the Aristotelian tradition. In: Hankins, J. (Ed.). The Cambridge companion to Renaissance philosophy. Cambridge: Cambridge University Press, 2007. p. 49-71.

Bolland, A. Art and humanism in early Renaissance Padua: Cennini, Vergerio and Petrarch on imitation. Renaissance Quarterly, 49, 3, p. 469-87, 1996.

Boskovits, M. Cennino Cennini: pittore non conformista. Mitteillungen des Kunsthistorischen Institut in Florenz, 22, p. 29-50, $197^{3 .}$

Cennnini, C. Il libro dell'arte. Firenze: Felice Le Monnier, 1859.

Chastel, A. Luigi d'Aragona, un cardinale del Rinascimento in viaggio per l'Europa. Bari: Laterza \& Figli, 1987 .

CLARK, K. \& Pedretti, C. (Ed.). The drawings of Leonardo da Vinci in the collection of her majesty the queen at Windsor Castle. London: Phaidon, 1969. v. 3: Anatomical drawings.

CLayton, M. Leonardo da Vinci. The anatomy of man. Drawings from the collection of Her Majesty Queen Elisabeth II. Comentários de anatomia R. Philo. Houston: The Museum of Fine Arts; Boston/Toronto/ London: Bulfinch/Little, Brown and Company, 1992.

Fabris, A. \& Kern, M. L. B. (Org.). Imagem e conhecimento. São Paulo: Edusp, 2006.

Frank, G.; Hallacker, A. \& Lalla, S. (Ed.). Erzählende Vernunft. Berlin: Akademie Verlag, 2006. 
GALluzzi, P. Leonardo's method: from the anatomy of machines to the man-machine. In: (Ed.). Leonardo da Vinci. Engineer and architect. Montreal: Montreal Museum of Fine Arts, 1987. p. 96-109. . Immagine e scrittura nella tradizione tecnica del Quattrocento. In: Leonardi, G.; MorelLi, M. \& Santi, F. (Ed.). Album: i luoghi dove si accumulano i segni. Spoleto: Centro Italiano di Studi sull'Alto Medioevo, 1995. p. 111-25. (Atti del Convegno di studio della Fondazione Ezio Franceschini e della Fondazione IBM Italia).

Garin, E. Ciência e vida civil no Renascimento italiano. São Paulo: Editora Unesp, 1994.

GHiberti, L. I comentarii. Introdução e notas L. Bartoli. Firenze: Giunti, 1998. (Biblioteca Nazionale Centrale di Firenze, II, I, 133).

Goffen, R. (Ed.). Masaccio’s Trinity. Cambridge: Cambridge University Press, 1998.

Gомввісн, E. H. Norm and form. Studies in the art of Renaissance. London: Phaidon Press, 1966.

Grayson, C. (Ed.). Opere volgari di Leon Batisti Alberti. Bari: Laterza, 1973. v. 3.

Hankins, J. (Ed.). The Cambridge companion to Renaissance philosophy. Cambridge: Cambridge University Press, 2007 .

Keele, K. \& Pedretti, C. (Ed.). Corpus of anatomical studies in the collection of her majesty the queen at Windsor Castle. London: Johnson Reprint Corporation, 1978-8o. 3 v. (K/P) . \& __. (Ed.). Leonardo da Vinci. Corpus degli studi anatomici nella collezione di sua maestà la regina Elisabetta II nel Castelo di Windsor. Firenze: Giunti Barbèra, 1980-85. 3 v. (K/P)

Kemp, M. Leonardo da Vinci. In: Turner, J. (Ed.). The dictionary of art. London: Macmillan Publishers Limited, 1996. v. 19, p. 180-99.

Koyré, A. Études d'historie de la pensée philosophique. Paris: Gallimard, 1971.

Kunn, H. Aristotelianism in the Renaissance. In: ZALTA, E. N. (Ed.). The Stanford encyclopedia of philosophy. Standford: Winter, 2009.

KristelLer, P. O. The modern system of the arts: a study in the history of aesthetics. Part 1. Journal of the History of Ideas, 12, 4, p. 496-527, $195^{1}$.

. The modern system of the arts: a study in the history of aesthetics. Part 2. Journal of the History of Ideas, 13,1, p. 17-46, 1952.

. Humanism. In: Schmitt, G. B.; Skinner, Q. \& Kessler, E. (Ed.). The Cambridge history of Renaissance philosophy. Cambridge: Cambridge University Press, 1988. p. 113-37.

Leinkauf, T. Kunst als 'proprium humanitatis'. Zum philosophischen Verständnis künstlerischer Gestaltung in der Renaissance. In: Frank, G.; Hallacker, A. \& Lalda, S. (Ed.). Erzählende Vernunft. Berlin: Akademie Verlag, 2006. p. 221-35.

Leonardi, C.; Moreldi, M. \& Santi, F. (Ed.). Album: i luoghi dove si accumulano i segni. Spoleto: Centro Italiano di Studi sull'Alto Medioevo, 1995. (Atti del Convegno di studio della Fondazione Ezio Franceschini e della Fondazione IBM Italia).

Leonardo da Vinci. Dell'anatomia fogli A. In: Sabachnikoff, T. (Ed.). I manoscritti di Leonardo da Vinci della Reale Biblioteca di Windsor. Introdução M. Duval. Transcrição e notas G. Piumati. Parigi: Edoardo Rouveyre, 1898. (Fogli A)

. Dell'anatomia fogli B. In: Sabachnikoff, T. (Ed.). Imanoscritti di Leonardo da Vinci della Reale Biblioteca di Windsor. Transcrição e notas G. Piumati. Torino: Roux e Viarengo, 1901. (Fogli B)

. Quaderni d'anatomia I-V. In: Vangensten, O.; Fonahan, A.; \& Hopstock, H. (Ed.). Comunicazione dello Istituto Anatomico dell'Università di Christiania. Christiania (Oslo): Jacob Dybwod, 1911-16. 6v. (Quaderni)

. Codice Madrid I. In: Retr, L. (Ed.). The Madrid codices. New York: McGraw-Hill Book Company, 1974. v. 4.

. Il manoscritto E. In: Marinoni, A. (Ed.). Il manoscritto E. Firenze: Giunti Barbèra, 1989.

. Libro di pittura. Firenze: Giunti, 1995. 2 v. 
A ciêngia visual de Leonardo da Vinci...

Manetti, A. Vita di Brunellesco. Firenze: Rinascimento del Libro, 1927.

Marinoni, A. (Ed.). Il manoscritto E. Firenze: Giunti Barbèra, 1989.

NAnni, R. La tecnica nel Panepistemon di Angelo Poliziano: mechanica e artes sellulariae. Physis, 44, 2, p. $349-76,2007$.

O’Malley, C. D. \& Saunders, J. B. De C. M. (Ed.). Leonardo on the human body. The anatomical, physiological and embriological drawings of Leonardo da Vinci. New York: Henry Schuman, 1952. (O’M\&S)

Panofsky, E. The Renaissance: six essays. New York: Harper \& Row, 1962.

PARK, K. Masaccios' skeleton: art and anatomy in early Renaissance Florence. In: Goffen, R. (Ed.). Masaccio's Trinity. Cambridge: Cambridge University Press, 1998. p. 119-40.

Racheli, A. (Ed.). Opere di Benedetto Varchi. Trieste: Sezione Letterario-Artistica del Lloyd Austriaco, 1859. v. 2.

REтI, L. Leonardo da Vinci and the graphic arts: the early invention of relief-etching. The Burlington Magazine, 133, 817, p. 188-95, 1971 .

Reti, L. (Ed.). The Madrid codices. New York: McGraw-Hill Book Company, 1974. v. 4.

Rossi, P. O nascimento da ciência moderna na Europa. Bauru: Unesc, 2001.

Sabachnikoff, T. (Ed.). I manoscritti di Leonardo da Vinci della Reale Biblioteca di Windsor. Introdução M. Duval. Transcrição e notas G. Piumati. Parigi: Edoardo Rouveyre, 1898.

. (Ed.). I manoscritti di Leonardo da Vinci della Reale Biblioteca di Windsor. Transcrição e notas G. Piumati. Torino: Roux e Viarengo, 1901.

Schwartz, G. \& Bishop, P. W. (Ed.). The development of modern science. New York: Basic Books, 1958. v. 2.

Sснмітт, G. B. Aristotle and the Renaissance. Cambridge/London: Harvard University Press, 1983.

Schmitt, C. B.; Skinner, Q. \& Kessler, E. (Ed.). The Cambridge history of Renaissancephilosophy. Cambridge: Cambridge University Press, 1988.

Singer, C. Astudy in early Renaissance anatomy, with a new text. The Anothomia of Hieronymo Manfredi (1490). In:___. (Ed.). Studies in the history and method of science. New York: Arno Press, 1975. v. 1, p. $80-164$.

Steneck. N. H. A late medieval "arbor scientiarum". Speculum, 50, 2, p. 245-69, 1975.

Tofani, A. P. Inventario di disegni esposti. Firenze: Gabinetto Disegni e Stampe degli Uffizi/Leo Olschki, 1987 . v. 1.

Turner, J. (Ed.). The dictionary of art. London: Macmillan Publishers Limited, 1996. v. 29.

Vangensten, O.; Fonahan, A.; \& Hopstock, H. (Ed.). Comunicazione dello Istituto Anatomico dell'Università di Christiania. Christiania (Oslo): Jacob Dybwod, 1911-16. 6v.

VARChI, B. Sopra la pittura e scultura: lezione due. In: Racheli, A. (Ed.). Opere di Benedetto Varchi. Trieste: Sezione Letterario-Artistica del Lloyd Austriaco, 1859. v. 2, p. 611-47.

VASARI, G. Le vite de' piu' eccellenti pittori, scultori e architettori scritte da Giorgio Vasari pittore e architetto aretino. Firenze: Audin, 1822.

Vasoli, G. The Renaissance concept of philosophy. In: Schmitt, C. B.; Skinner, Q. \& Kesssler, E. (Ed.). The Cambridge history of Renaissance philosophy. Cambridge: Cambridge University Press, 1988. p. 57-74.

Vesalius, A. The preface of Andreas Vesalius his own books on the anatomy of the human body addressed to the most great and invincible emperor the divine Charles V. In: Schwartz, G. \& Bishop, P. W. (Ed.). The development of modern science. New York: Basic Books, 1958. v. 2, p. 517-32.

ZaLta, E. N. (Ed.). The Stanford encyclopedia of philosophy. Standford: Winter, 2009.

Wallage, W. A. Traditional natural philosophy. In: Sснmitt, C. B. \& Skinner, Q. \& Kessler, E. (Ed.). The Cambridge history of Renaissance philosophy. Cambridge: Cambridge University Press, 1988. p. $201-35$. 